University of Miami Law School

University of Miami School of Law Institutional Repository

Articles

Faculty and Deans

2007

Hedge Funds and Governance Targets

William Wilson Bratton

Follow this and additional works at: https://repository.law.miami.edu/fac_articles

Part of the Law Commons 


\title{
ARTICLES
}

\section{Hedge Funds and Governance Targets}

\author{
WilLiam W. BRATton*
}

\begin{abstract}
Corporate governance interventions by hedge fund shareholders are triggering debates between advocates of management empowerment and advocates of aggressive monitoring by actors in the capital markets. This Article intervenes with an empirical question: What, based on the record so far, have the hedge funds actually done to their targets? Information has been collected on 130 domestic firms identified in the business press since 2002 as targets of activist hedge funds, including the funds' demands, their tactics, and the results of their interventions for the targets' governance and finance. The survey results show that the hedge funds have an enviable record in getting targets to accede to their demands, using the proxy system with remarkable, perhaps unprecedented, success. If the pattern of intervention persists in time, expands its reach, and maintains the present high level of governance success, then the separation of ownership and control will become a less acute problem for corporate law. Such a change will occur, however, only to the extent that clear cut financial incentives encourage an expanded field of intervention. To get a sense of the sample's bearing on the question as to such incentives' existence, returns from hedge fund engagement with the sample firms are compared to returns from market indices. The results are mixed. The answer to the question whether the activists have beaten the market depends on the assumptions one brings to the comparison. But it at least can be argued that the hedge funds have not beaten the market respecting the targets in the sample. A question accordingly arises respecting the depth and durability of any shift in the balance of corporate power stemming from hedge fund activism. Meanwhile, the financial results also show that hedge fund activism is a more benign phenomenon than its critics would have us believe. Hedge fund interventions neither amount to near-term hold ups nor revive the 1980 s leveraged restructuring. Short term investments are rare. Large cash payouts have been made by only a minority of the firms surveyed, and borrowing has been the mode of finance in only a minority of the payout cases.
\end{abstract}

TABLE OF CONTENTS

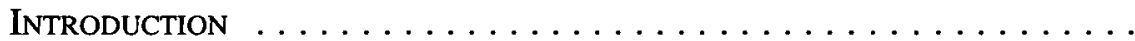

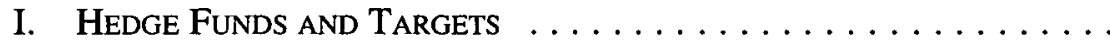

A. THE ACTIVIST FUNDS AND THEIR INSTITUTIONAL CONTEXT $\ldots \ldots$

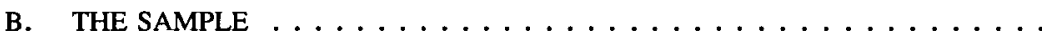

* Professor of Law, Georgetown University Law Center; Research Associate, European Corporate Governance Institute. (C) 2007, William W. Bratton. For suggestions and comments, my thanks to Florencio López-de-Silanes, Joe McCahery, Frank Partnoy, Armin Schwienbacher, Randall Thomas, and Kathy Zeiler, along with participants at faculty workshops at the British Columbia, George Mason, Wisconsin law schools and participants at the Law and Business Conference on Investor Activism at Vanderbilt Law School, the Virginia Law and Business Symposium, and the Conference on Activist Investors, Hedge Funds, and Corporate Governance at the University of Amsterdam. For research assistance, my special thanks to Stephanie Lyerly, Georgetown Law. 
C. INVESTMENT POSITIONS . . . . . . . . . . . . . . . . 1387

D. TARGET CHARACTERISTICS . . . . . . . . . . . . . 1390

1. Sale . . . . . . . . . . . . . . . . . . . . . . . 1390

2. Unbundling .................... 1392

3. Cash . . . . . . . . . . . . . . . . . . . . . . 1394

4. Good Assets, Bad Managers . . . . . . . . . . . . 1396

E. TARGET PERFORMANCE . . . . . . . . . . . . . . . . . . 1397

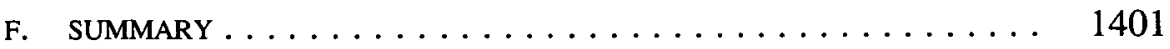

II. Strategies, Outcomes, And the Balance of Power $\ldots \ldots \ldots .1401$

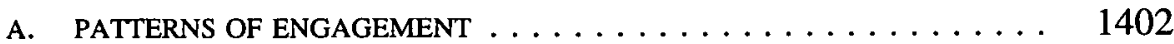

1. Initial Engagement . . . . . . . . . . . . . 1402

2. Target Resistance, Hedge Fund Attack . . . . . . . . . 1403

B. OUTCOMES ....................... 1405

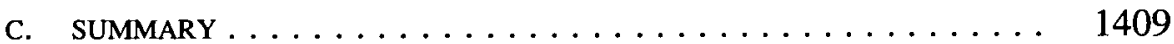

III. Financial Outcomes $\ldots \ldots \ldots \ldots \ldots \ldots \ldots \ldots \ldots \ldots . \ldots \ldots$

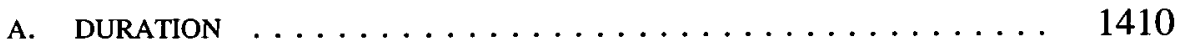

B. $\quad \operatorname{cost}$ CUTting $\ldots \ldots \ldots \ldots \ldots \ldots \ldots \ldots \ldots \ldots \ldots \ldots \ldots \ldots \ldots$

C. CASH PAYOUTS AND BORROWING $\ldots \ldots \ldots \ldots \ldots \ldots \ldots .1415$

D. PORTFOLIO RETURNS $\ldots \ldots \ldots \ldots \ldots \ldots \ldots \ldots \ldots \ldots \ldots \ldots$

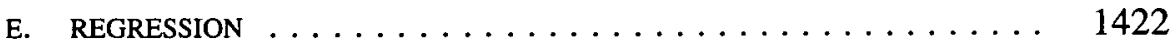

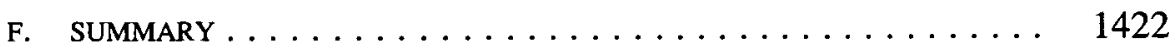

IV. Hedge Fund Activism AND the Market for Corporate Control . . . . . . . . . . . . . . . . . . . . . . 1422

A. THE SAMPLE $\ldots \ldots \ldots \ldots \ldots \ldots \ldots \ldots \ldots \ldots \ldots \ldots \ldots \ldots \ldots \ldots$

B. POLICY IMPLICATIONS $\ldots \ldots \ldots \ldots \ldots \ldots \ldots \ldots \ldots \ldots$

C. ACTIVISTS AS PURCHASERS $\ldots \ldots \ldots \ldots \ldots \ldots \ldots \ldots \ldots$

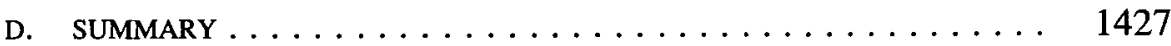

ConcLusion . . . . . . . . . . . . . . . . . . . . . . . . . 1427

APPENDIX A: Governance INTERvention SAMPLE . . . . . . . . . 1429 


\section{INTRODUCTION}

On July 26, 2004, Mylan Laboratories, a generic drug producer, announced its agreement to acquire another drug company, King Pharmaceuticals, in a stock for stock merger. The deal valued King at $\$ 16.66$ per share, ${ }^{1}$ a generous $61.8 \%$ premium over its day-before market price. Too generous, thought traders in Mylan stock, which promptly dropped from $\$ 18.51$ to $\$ 15.51$. But Mylan stock had at least one buyer that day, Carl Icahn, who purchased one million shares. He continued buying over the next six weeks, investing $\$ 307$ million and finally revealing himself as the owner of $6.8 \%$ of the company in a Securities and Exchange Commission (SEC) 13D filing. He simultaneously denounced the deal as an overpriced acquisition of a weak company and announced his intention to mount a proxy fight against it at the shareholders' meeting to be convened for its approval. ${ }^{2}$ Icahn got what he wanted without having to incur the cost to solicit proxies; Mylan itself terminated the agreement in January 2005 , citing adverse facts discovered in the due diligence process. ${ }^{3}$

Complications arose along the way. Icahn's frontal attack on the merger put him at odds with other Wall Street players. In the wake of a merger announcement, the more usual "risk arbitrage" move is to buy shares of the target (so as to benefit from any increase in the merger price) and simultaneously sell shares of the acquirer short (so as to benefit from any further decline in its price due to the merger). Richard C. Perry, a hedge fund manager and risk arbitrage player, did just that in Mylan's case, but with a twist. Wishing to protect the merger (and thus his investment), he purchased Mylan stock in an amount matching his short position, thereby gaining control of $10 \%$ of the votes at the upcoming meeting. ${ }^{4}$ Icahn called a foul on the grounds that Perry's long/short position left him without an economic interest in Mylan. It followed, said Icahn, that Perry, despite his record ownership, should not have the privilege to vote the shares. "Corporate democracy," he wrote, "is a cornerstone of our capitalist system. A few hedge funds should not be permitted to destroy it in order to make a few extra bucks." Icahn sued, but the merger's cancellation mooted the matter. ${ }^{6}$

1. Mylan Labs. Inc., Mylan Laboratories To Acquire King Pharmaceuticals (Form 425), at 1-2 (July 26, 2004)

2. Mylan Labs. Inc. (Schedule 13D) (Sept. 7, 2004) (filed by Carl C. Icahn et al.); Mylan Labs. Inc., Preliminary Proxy Soliciting Materials (Schedule 14A) (Sept. 8, 2004) (filed by Carl C. Icahn et al.).

3. Mylan Labs. Inc., Mylan Comments on King Transaction (Form 425) (Jan. 12, 2005).

4. Mylan Labs. Inc., (Schedule 13D) (Nov. 29, 2004) (filed by Steve Perry Corp. et al.).

5. Mylan Labs. Inc., Additional Definitive Preliminary Proxy Soliciting Materials (Schedule 14A) (Dec. 6, 2004) (filed by Carl C. Icahn et al.).

6. See High River Ltd. P'ship v. Mylan Labs., Inc., 383 F. Supp. 2d 660 (M.D. Pa. 2005). The SEC is investigating whether Perry violated disclosure rules. See Andrew Ross Sorkin, S.E.C. Plans To Accuse Hedge Fund of Violations, N.Y. TIMEs, Jan. 11, 2006, at C3. 
Icahn's challenge to Perry's votes raised an important question about the law of shareholder voting, a question well-investigated elsewhere. ${ }^{7}$ This Article concerns what happened at Mylan after the merger's cancellation.

Icahn, looking for a few extra bucks himself, did not go away. Backed by a report prepared by an industry consultant, he had already attacked Mylan's wider business strategy. The company, said Icahn, should be sold. Indeed, he announced his willingness to buy it for $\$ 20$ per share. He added that the company's board needed more outside directors and that it paid its chief executive officer more than the performance record justified. ${ }^{8} \mathrm{He}$ announced his intention to propose an opposition slate of directors at Mylan's 2005 annual meeting. Its managers responded by delaying the meeting and amending its bylaws to include a preclusive advance notice requirement. ${ }^{9}$ Icahn countered with a second lawsuit. ${ }^{10}$

That action, too, was mooted. Mylan's managers, seeking to satiate Icahn and neutralize his threat to their control, announced a $\$ 1.25$ billion share repurchase to be funded by a billion dollar line of credit. ${ }^{11}$ Icahn dismissively responded that the price they offered "for the most part" fell below his $\$ 20$ offer. Nonetheless, he took his pro rata share of the buyback pot just the same, dropping both the proxy fight and the offer to purchase, and selling the rest of his shares into the market. ${ }^{12}$

As he made his exit from this thirteen month investment, Icahn noted that Mylan's stock now traded 32\% higher than it had prior to his appearance. ${ }^{13} \mathrm{He}$ did not mention the fact that he had left behind a different company. Pre-Icahn, Mylan had $\$ 1.8$ billion of shareholders' equity and no debt. Post-Icahn, its shareholders' equity stood at $\$ 787$ million and long-term debt at $\$ 685$ million. ${ }^{14}$ While this $87 \%$ ratio of debt to equity did not make Mylan a highly-levered company, it certainly left it much encumbered and correspondingly constrained its managers' freedom of action.

This Carl Icahn caper is a famous example of hedge fund shareholder

7. See Henry T.C. Hu \& Bernard Black, The New Vote Buying: Empty Voting and Hidden (Morphable) Ownership, 79 S. CAL. L. REv. 811, 875-86 (2006) (recommending full disclosure respecting the voter's economic interest); Shaun Martin \& Frank Partnoy, Encumbered Shares, 2005 U. ILL. L. REv. 775, 804-09 (recommending that economic interest be a precondition to the vote); Larry Ribstein \& Bruce Kobayashi, Outsider Trading as an Incentive Device, 40 U.C. DAviS L. REv. 21, 38-47 (finding that vote-buying presents little problem and viewing disclosure as the maximal regulatory response).

8. Mylan Labs. Inc., Additional Definitive Preliminary Proxy Soliciting Materials (Schedule 14A), at 3-4 (Nov. 22, 2004) (filed by Carl C. Icahn et al.).

9. Mylan Labs. Inc., Current Report (Form 8-K), at 3-4 (Feb. 22, 2005).

10. Mylan Labs. Inc., Additional Definitive Preliminary Proxy Soliciting Materials (Schedule 14A, Exhibit A) (Feb. 22, 2005) (filed by Carl C. Icahn et al.).

11. Mylan Labs. Inc., Current Report (Form 8-K) (June 14, 2005).

12. Mylan Labs. Inc., Additional Definitive Preliminary Proxy Soliciting Materials (Schedule 14A) (July 18, 2005) (filed by Carl C. Icahn et al.).

13. Id.

14. Mylan Labs. Inc., Annual Report (Form 10-K), at 40 (May 16, 2006). 
activism. Hedge funds have emerged as aggressive shareholders at many firms in recent years. They target companies, take large positions in their stock, criticize their business plans and governance practices, and confront their managers, demanding action that enhances shareholder value. When one hedge fund announces a $5 \%$ or $10 \%$ position in a company, others follow, forming a "wolf pack" that sometimes has the voting power to force management to address its demands. The demands, in turn, likely include one or more actions assuring a quick return on investment-sale of the company at a premium, unbundling of the company through the sale or spin off of a large division, or a large cash payment to the shareholders in the form of a special dividend or share repurchase. The activists pack their biggest punch at small companies where their investments translate into large voting blocks. But they also have confronted giants like General Motors, McDonald's, and Time Warner. Their financial power has led to respectability on Wall Street, where they have become clients of investment banks like Lazard and UBS and law firms such as Sullivan \& Cromwell and Wachtell Lipton. ${ }^{15}$

Not everyone at the Wachtell firm approves, however. Its senior partner, Martin Lipton, predicts negative economic consequences: "We have," he says, "gone from the imperial CEO to the imperial stockholder." ${ }^{16}$ Critics like Lipton ask why, between a team of managers who have been running a firm for years and an outside activist looking for above-market returns in the current period, the activist's judgment about the best way to run the business should command respect. ${ }^{17}$ The activists, they say, survey a target with a bias toward near-term gain, ${ }^{18}$ regardless of its future, the interests of its long-term investors, ${ }^{19}$ and the productivity of the wider economy. ${ }^{20}$ Hedge fund pressure on present and potential targets is thought to constrain investment policy negatively, ${ }^{21}$ skewing managers away from promising but difficult-to-value projects toward less promising but more easily valued projects. Where, as with Mylan, an activist extracts a payout financed by debt, the ongoing cash drain could leave the target vulnerable to distress in the economy's next downturn. ${ }^{22}$ Others warn of darker possibilities like lucrative side deals between unscrupulous funds and frightened

15. See Julie Fishman-Lapin, Vilified by Some, Activist Investors Promote Market Efficiency, StamFORD ADvo., June 4, 2006; Brent Shearer, Dangerous Waters for Dealmakers: Shareholder Sharks Are Using Their Clout To Influence Deals, MeRGeRs \& AcQuistTIONs, Mar. 1, 2006.

16. Battling for Corporate America-Shareholder Democracy, ECoNomIST, Mar. 11, 2006, at 160.

17. Shearer, supra note 15.

18. Taken as a group, the hedge funds do pursue short term returns, contributing from one-third to one-half of daily trading volume while owning only $5 \%$ of total assets. Marcel Kahan \& Edward B. Rock, Hedge Funds in Corporate Governance and Corporate Control 32-33 (Univ. of Pa. Inst. for L. \& Econ., Research Paper No. 06-16, 2006), available at http://ssrn.com/abstract $=919881$.

19. See, e.g., Steven Schurr, Fruitless? Activist Shareholders Could Be Losing Their Ability To Shake Managements, FIN. TIMEs (London), Jan. 11, 2006, at 19.

20. See id.

21. Kahan \& Rock, supra note 18 , at $47-50$.

22. Shearer, supra note 15. 
managers ${ }^{23}$ or feigned interventions that create short term trading opportunities.

The activists and their defenders reply with a wave of the shareholder value banner: Given recent corporate scandals, endless discussions about supine boards of directors, and current debates over excess pay, somebody ought to be holding the managers' feet to the fire. ${ }^{24}$ Cash payouts should be applauded: Managers should pay out capital for which the company has no good use, turning the job of reinvestment over to capital markets better suited to the task. Corporate cash payouts, while rising recently, have yet to surpass historical levels. ${ }^{25}$ Meanwhile, the activist funds operate subject to constraints. For example, if a given fund also invests on a cooperative basis, its reputational interest lies in assuring that criticisms are soundly based. ${ }^{26}$ Nor does wolf pack voting always predetermine a hostile engagement's outcome. An alternative business plan must persuade the wider community of institutional investors and informational intermediaries, many of whom can be counted on to reject unsound, short term interventions.

This Article intervenes in this debate with an empirical question: What, based on the record so far, have the hedge funds actually done to their targets? To address the question, it collects information on 130 domestic firms identified in the business press since 2002 as investment targets of "activist" hedge funds, surveying the funds' demands, their tactics, and the results of their interventions for the targets' governance and finance. The results show that the Mylan case is representative in three respects-it is typical as regards the occasion for the intervention, the demands made, and the tactics employed. As to outcome, however, the case is an outlier; Mylan's payout is unusual both for its magnitude and the borrowing that financed it. Large payouts have been made by a minority of the firms surveyed, with borrowing as the mode of finance in only a minority of the payout cases. Icahn's thirteen month round trip investment also turns out to be unusual; the activists more typically invest for an intermediate term of two years or longer. Whether some stay longer still with their targets remains to be seen, but such occurrences do not appear unlikely based on the facts collected here. ${ }^{27}$

23. Kahan \& Rock, supra note 18 , at 46.

24. Schurr, supra note 19 , at 17.

25. John Authers, Value Investing: Hoping To Update the Magic Formula, Fin. Times (London), Nov. 22,2005 , at 14 (noting that some economists warn against the negative impact of cash payouts while others argue that companies are only now finally getting payouts back to historic levels).

26. Schurr, supra note 19 (quoting fund manager David Nierenberg).

27. Two draft financial economic studies based on overlapping data sets have appeared. See April Klein \& Emanuel Zur, Hedge Fund Activism (ECGI Finance, Working Paper No. 140/2006), available at http://ssm.com/abstract=913362; Alon Brav et al., Hedge Fund Activism, Corporate Governance, and Firm Performance (Sept. 22, 2006) (unpublished manuscript, on file with author). There also is a draft study of activist investments made by the British fund, Hermes. See Marco Becht et al., Returns to Shareholder Activism: Evidence from a Clinical Study of the Hermes U.K. Focus Fund (ECGI Finance, Working Paper No. 138/2006), available at http://ssrn.com/abstract $=934712$. For a brief study that references several cases in this Article's sample, see David Haarmeyer, The Revolution in Active Investing: Creating Wealth and Better Governance, J. ApPLIED CoRP. FIN., Winter 2007, at 25, 32-35. 
This Article concludes that, based on the record so far, hedge fund activism is a more benign phenomenon than its critics would have us believe. Certainly, it is uncooperative and disruptive, viewed from the point of view of a target's managers. But it is not a slash and burn repeat of the high leverage, bust-up takeovers of the 1980s. Nor does it necessarily retain an uncooperative character as the engagement between a target and a fund evolves over time. Activists have joined many target boards of directors, modifying their tactics in so doing.

That said, a question arises concerning the new activists' potential to alter permanently the balance of power between managers and shareholders. Berle and Means first described corporate governance as a problematic separation of ownership and control more than seventy-five years ago. ${ }^{28}$ Solutions to the problem have been announced on two occasions since-first with the hostile takeovers of the $1980 \mathrm{~s}^{29}$ and then, more hesitantly, with the appearance of activist investment institutions in the $1990 \mathrm{~s}^{30}$ Both announcements proved premature. With the hedge funds, a newly configured shareholder interest breaches the governance divide for the third time. This Article will show that the activist funds have employed the proxy system, widely thought to be moribund, ${ }^{31}$ with remarkable, perhaps unprecedented, success. ${ }^{32}$ If this pattern of intervention persists in time and expands its reach, the separation of ownership and control could become a less acute governance problem. The analysis here, however, registers a question about the change's depth and durability. The separation of ownership and control will yield only to the extent that clear cut financial incentives encourage shareholder intervention. This Article's review of financial results does not confirm the presence of such incentives. Nor, however, does it negate them.

Part I describes the data set-the characteristics of the hedge funds, their investment positions, and the target companies. Part II describes the tactics that the hedge funds employ and the governance results, showing that the hedge funds have an enviable success record at getting targets to accede to their demands, whether by force or persuasion. Part III looks at financial results-the duration of hedge fund investments in targets, levels of cost-cutting at target firms, levels and financing of cash payouts, and the targets' stock market performances. These results, while less earth-shaking, bear importantly on policy debates. Short-term investments are rare. Targets have rarely been slash-

28. See Adolf A. Berle, Jr. \& Gardiner C. Means, The Modern Corporation and Private Property 112-16 (William S. Hein \& Co. 2000) (1933).

29. William W. Bratton, Berle and Means Reconsidered at the Century's Turn, 26 J. CORP. L. 737, 755-56 (2001).

30. Bernard S. Black, Agents Watching Agents: The Promise of Institutional Investor Voice, 39 UCLA L. REv. 811, 886-88 (1992) (describing institutional voice as a partial palliative).

31. See Lucian Arye Bebchuk, The Case for Increasing Shareholder Power, 118 HARv. L. Rev. 833, 851-64 (2005) (discussing the operation of the shareholder voting system in issue-based contests); Lucian Arye Bebchuk, The Myth of the Shareholder Franchise, 93 VA. L. Rev. (forthcoming 2007) (discussing data on fully prosecuted proxy contests).

32. See infra note 106 and accompanying text. 
ing costs in the wake of hedge fund intervention. Cash payouts, while substantial, do not cripple the targets, which tend to fund them with the proceeds of asset sales. A comparison of investment returns from hedge fund engagement to returns from market indices yields mixed results-the answer to the question whether the activists have beaten the market depends on the assumptions one brings to the exercise of comparison. However, it can at least be argued that the hedge funds have not beaten the market respecting the targets in this Article's sample. Part IV looks at a subset of cases in which the hedge funds intervene to terminate or alter announced mergers. The success record is again impressive. In addition, with mergers, the productivity implications of the activist intervention are notably positive.

\section{HEdGe FundS AND TARgETS}

This Part begins by situating the activist hedge funds within the wider community of investment institutions. It then goes on to describe the case sample, breaking out the characteristics of the target firms and the funds' investment positions.

\section{A. THE ACTIVIST FUNDS AND THEIR INSTITUTIONAL CONTEXT}

Although hedge funds resist one-line definition, their regulatory status at the moment is clear enough: They lie outside the bounds of federal regulation of mutual funds, other investment companies, and their advisors. ${ }^{33}$ Regulatory classification, however, does not tell us what hedge funds do. Private equity funds occupy the same unregulated space and appeal to the same class of investors, and, like hedge funds, lever their portfolios. ${ }^{34}$ Until recently, we could distinguish hedge funds from private equity by the characteristics of their investments. Private equity, the successor to the leveraged buyout funds of the 1980s, takes companies private, investing long-term in their equity from a control position. Hedge funds, in contrast, play securities markets worldwide. Private equity firms possess expertise in company analysis. Hedge funds, in contrast, employ "numbers guys" expert in complex market arbitrage. ${ }^{35}$ Different hedge funds concentrate on different market plays. Some specialize in securities of distressed firms, while others make directional bets on the movement of currency exchange or interest rates. Still others pursue convertible arbitrage, going long in a

33. Hedge funds are exempt from the Investment Company Act of 1940 because they either have 100 or fewer beneficial owners and do not offer their securities to the public, see 15 U.S.C. $\S 80 \mathrm{a}-3(\mathrm{c})(1)(2000)$, or because their investors are all qualifying wealthy individuals or institutions, see id. $\S 80 \mathrm{a}-3(\mathrm{c})(7)$. For their status under the Investment Advisers Act of 1940, 15 U.S.C. $\$ 80 \mathrm{~b}-1$ to -21 , see Goldstein v. SEC, 451 F.3d 873 (D.C. Cir. 2006), which vacates and remands the SEC's "Hedge Fund Rule." See also Registration Under the Advisers Act of Certain Hedge Fund Advisers, 69 Fed. Reg. 72,054 (Dec. 10, 2004) (codified at 17 C.F.R. pts. 275, 279). The plaintiffs in the case included the governance activist Philip Goldstein and his Opportunity Partners.

34. See Kahan \& Rock, supra note 18 , at 30 (noting that $30 \%$ of hedge funds use a 2 -to-1 leverage ratio, while another $40 \%$ lever at lower ratios).

35. Irwin A. Kishner \& Kacey M. Foster, The New Masters of the Buyout Universe, 234 N.Y. L.J. 11 (2005). 
convertible bond and shorting the underlying common stock. ${ }^{36}$ Many follow market momentum, moving in groups in and out of asset classes worldwide. ${ }^{37}$ Recently, some have taken up risky lending, funding leveraged buyouts and firms in bankruptcy reorganization, and trading in junk bonds and credit derivatives. ${ }^{38}$ The tie that binds the hedge funds together, despite the variety of investment styles, is their promise to deliver above-market returns, a task that becomes harder and harder as more funds pursue the same strategies.

One subset of hedge funds invests in domestic equities in the classic, value investor mode. ${ }^{39}$ The activist funds tend to come from this value-directed group. They maintain concentrated portfolios and often avoid the hedged or multistrategy approaches followed by other funds, ${ }^{40}$ with their managers tending to be former investment bankers or research analysts rather than quantitative experts. They do the research and know their targets well, much like the private equity firms. ${ }^{41}$ Some of their managers even profess to be followers of Graham and Dodd, the mid-twentieth century financial writers whose work remains a fundamental text of value investment. ${ }^{42}$

But their activist interventions break with the Graham and Dodd tradition. The leading value exponent, Warren Buffett, invests long-term and stays patient, following the same cooperative strategy as the private equity investors. ${ }^{43}$ The activists lack this patience. They look for value but want it realized in the near or intermediate term. Their strategy is to tell managers how to realize the value and to challenge publicly those who resist their advice.

Private equity also actively reshapes business plans, but does so behind closed doors over periods of years, after buying the company and taking it private. Differences in governing investment contracts parallel these different behavior patterns. Contracts governing investment in hedge funds typically lock up investor capital for six months, although some now impose terms of two

36. See A.V. Rajwade, Markets and Hedge Funds, Bus. Standard, Mar. 27, 2006.

37. Roben Farzad, Blue Chip Blues; How Long Will the Stocks of America's Largest Companies Remain Weaklings on Wall Street?, Bus. WK., Apr. 17, 2006, at 21.

38. Rajwade, supra note 36.

39. The search for value takes them to small- and mid-capitalization companies that are underresearched and thus passed over by mainstream investment institutions. Such stocks have become harder to find lately. Large-capitalization stocks have languished in recent years-over the last five years, the Standard \& Poor's 500 index has returned only $4.3 \%$ per year. Farzad, supra note 37 , at 66. Forward momentum in domestic equity markets has occurred only in the small- and mid-cap sectors. Valuations have compressed, making cheap stocks harder to identify, and volatility has decreased, reducing opportunities to catch a bargain. Authers, supra note 25 , at 14 .

40. Some of the value funds do hedge variation, following a long/short strategy, going long in undervalued stock and short in overvalued stock in search of returns independent of the direction of the market. Rajwade, supra note 36.

41. See Fishman-Lapin, supra note 15.

42. See Authers, supra note 25 , at 14 (describing hedge fund participants at the Value Investing Congress for followers of Ben Graham's investment theory).

43. See Roger Lowenstein, Buffett: The Making of an American Capitalist, at xiii-xvi (1995). 
years or longer. ${ }^{44}$ Contracts governing private equity investment tend to lock up investments for five years, with some contracts going as far as ten years. ${ }^{45}$ These more liberal arrangements facilitate not only large, illiquid, and longterm equity positions, but patience. In contrast, the hedge funds' shorter durations, when coupled with the large, illiquid positions, invite aggression and impatience. Of course, nothing in present practice dictates the terms of the activists' future arrangements with their investors. If they obtain longer lockups, modified strategies may follow.

The activists' aggressive stance respecting management business decisions also distinguishes them from the investment managers of mutual and pension funds. Observers of corporate governance have spent two decades encouraging these fund advisors to take the lead for the shareholder interest and actively challenge the authority of unsuccessful corporate managers. But the requisite financial incentives never have fallen into place. Collective action problems, conflicts of interest, and investment duration all stand in the way. The free rider problem discourages investment managers from incurring the costs of challenges-gains must be shared with competitors who do not share costs. At the same time, many fund advisors sell services to managers, importing an independent business reason to stay cooperative. ${ }^{46}$ Finally, mutual fund investors can redeem at any time, inhibiting investment in large, illiquid positions. Meanwhile, the hedge funds face none of these barriers. They take investment positions large enough to minimize free rider problems. Gains shared within the wolf pack do not appear to inhibit the funds that take the lead in proxy fights or bring lawsuits against recalcitrant firms. The funds' managers have every reason to be aggressive in realizing value, earning not only $2 \%$ of assets under investment but $20 \%$ of the profits. ${ }^{47}$ Small size and focused strategy minimizes conflicts of interest. And, as we have seen, the governing investment contracts allow them to lock up capital for longer periods than do the mutual funds.

A final contrast between the activists and mainstream investment advisors should be noted. The activists, as value investors, have a better record as financial monitors. Only two members of the financial community challenged Enron in advance of the press. One was a Houston analyst of energy stocks. ${ }^{48}$

44. See Kishner \& Foster, supra note 35, at 11. Some funds operate under caps on the percentage of illiquid assets, putting their illiquid holdings into pockets separate from the rest of the fund. See id.; see also Kahan \& Rock, supra note 18 , at 31.

45. Kishner \& Foster, supra note 35, at 11.

46. See, e.g., Stephen M. Bainbridge, Director Primacy and Shareholder Disempowerment, 119 HARV. L. REV. 1735, 1751-54 (2006) (describing the incentive problems of institutional investors); Kahan \& Rock, supra note 18, at 20-26 (summarizing impediments to mutual managers' ability to act as effective and activist monitors). On the free rider problem, see Jill Fisch, Relationship Investing: Will it Happen? Will it Work?, 55 Oніо ST. L.J. 1009, 1012 (1994), which observes that a rational investor will not intervene if the effect is to confer a benefit on free-riding competitors.

47. See Rajwade, supra note 36.

48. See Bethany Mclean \& Peter Elkind, The Smartest Guys in the Room: The Amazing Rise and SCANDalous Fall of EnRon 233-35 (2003). 
The other was Richard Grubman, the managing director of Highfields Capital Management, one of the leading activist firms. Grubman later would be accused by Jeffrey Skilling in trial testimony of being the head of a short-selling ring responsible for bringing down the company. ${ }^{49}$ The accusation was nonsense, of course. Nonetheless, it is ironic now to be asking whether Grubman and others like him amount to a corporate governance policy problem.

\section{B. THE SAMPLE}

Appendices A and B list the firms in this Article's sample of cases of hedge fund intervention. Each of the 130 domestic firms included was cited in the business press between January 1, 2002 and June 30, 2006 as a target of an "activist" hedge fund. ${ }^{50}$ The 114 firms listed in Appendix A comprise the sample-in-chief. The row for each target firm includes: (a) the year of the first such press report or, if earlier, the year of investment, ${ }^{51}$ (b) the first hedge fund reported to have taken an active investment position, and (c) the maximum percentage of shares held by the hedge fund during its period of ownership or through December 31, 2006 for continuing investments. Appendix B sets out an additional 16 firms that experienced hedge fund intervention limited to a single merger transaction.

The search's objective is a representative sample of active and adversary hedge fund equity investment. Because the selection has been left to databases of press reports, the sample is accordingly unrepresentative of hedge fund equity investment taken as a whole. ${ }^{52}$ Hedge fund shareholders can be passive as well as active and cooperative as well as adversarial. ${ }^{53}$ The question is whether the sample results in a skewed presentation of adversary investment, in particular by leading to an under- or overstatement of the number of successful outcomes. Larger targets are probably overrepresented, larger being more newsworthy. This fact could lead to understatement of success to the extent that larger firms imply a higher level of difficulty. However, the rate of success turns out to be quite high at all events. A question also comes up as to overstatement of success, assuming the hedge funds themselves engage the press in building reputations and challenging targets. But overstatement respecting results seems an unlikely result of hedge fund manipulation of the press-engagement is

49. Grubman was the conference call participant who criticized Jeffrey Skilling for the firm's balance sheet not being ready, only to be called an "asshole." See Andrew Clark, Enron Defendant Accuses Analyst, The Guardian (London), Apr. 14, 2006, at 26.

50. The following search request was input into the Factiva and Lexis/Nexis databases: "hedge fund" and shareholder and activist.

51 . Where the commencement of hedge fund activity antedates the year of the first press report, the year of commencement is listed if 2002 or later.

52. It should be noted that this is not a study of hedge fund investment style. For a study of investment style, see generally Douglas Cumming et al., Style Drift in Private Equity (Apr. 25, 2005) (unpublished manuscript), available at http://ssrn.com/abstract $=729684$. This Article is a study of the interaction between hedge funds and targets with a stress on the targets.

53. See Susan L. Barreto, Activists Aligned for Long-Term Success, HedgeWorld Dally News, Mar. $30,2006$. 
newsworthy per se, press reports tend to begin in advance of the outcome, and both sides have access.

Two additional issues respecting the sample's parameters need to be noted. The first concerns the characteristics of the investing fund. All of the funds well-known in recent years for aggressive investment show up on the list. ${ }^{54}$ Some, however, might object to the "hedge fund" denomination. For example, Relational Investors, which in 2006 conducted a high-profile battle against the managers of Sovereign Bancorp, operates solely as a long-term equity investor and runs no short positions. ${ }^{55}$ Strictly speaking, therefore, it is a fund without hedges. As a value investor, however, it fits the profile here. Franklin Mutual Advisers, a mutual fund advisor, shows up in two cases, both times representing itself as acting on behalf of unnamed advisory clients; Morgan Stanley also shows up, acting on its own account. ${ }^{56}$ Their engagements' characteristics have not differed at all from those of the hedge funds; their targets, accordingly, have been left in the sample. The same goes for Tracinda, which invests Kirk Kerkorian's money in businesses like casinos and movie studios and does not appear to invest on behalf of third parties. Its intervention against General Motors has been grouped with those of the hedge funds by outside observers generally, and this Article follows suit. The sample contains, in effect, hedge fund activists and other investment institutions that act like them.

The second definitional problem concerns the character of the engagement. Seven of the investment positions yielded by the search (Martha Stewart, Heidrick \& Struggles, Kmart, Sears, Krispy Kreme, Unisource, and Reynolds and Reynolds) were cooperative upon initiation and retained that posture. They have been left in the sample toward the end of minimizing ex post qualitative manipulation. ${ }^{57}$ A strong argument nonetheless can be made for omitting Kmart and its subsequent acquisition, Sears. Edward Lampert and his ESL Partners

54. Specifically, Steel Partners II (9), Highfields Capital Management (6), Pirate Capital (6), Third Point Management (6), ValueAct Capital (5), Barington Partners (5), JANA Partners (5), Carl Icahn \& Co. (5), Newcastle Partners (4), Chapman Capital (4), K Capital (2), ESL Partners (2), Cannell Capital (2), MMI Investments (2), Appaloosa Management (2), Caxton Corp. (2), and Trian Partners (Nelson Peltz) (2), BP Capital Energy (Boone Pickens) (1), Relational Investors (1), Pershing Square (1), and Tracinda Corp. (Kirk Kerkorian) (1).

55. John Dizard, Sovereign Dispute a Symbol of Something Bigger, Fin. Thmes (London), Feb. 7, 2006, at 11 .

56. See Farmer Bros. Co. (Schedule 13D) (Nov. 20, 2000) (filed by Franklin Mutual Advisers LLC); Phyllis Plitch, Efforts To End Dual-Class Share Structures Draw Votes, Dow Jones Newswires, May 24, 2006 (describing activist intervention by Franklin and Morgan Stanley against dual class common capital structures).

57. Three cases of adverse activity, each involving attempts to open up closed-end investment companies selling at a discount, have been omitted. Four other investments have been omitted as false positives: (1) ValueAct's investment in MedQuist, because MedQuist has a 75\% majority owner; (2) Cendant, reported as a target of hedge fund complaints, because no fund has emerged either in a leadership role or in a 13D filing; (3) Morgan Stanley, despite the fact that hedge fund criticism was reported in connection with its recent CEO change, because the complaining fund had a trivial stake in the firm and events in the firm can be more plausibly ascribed to internal politics than external pressure; and (4) Albertsons, the subject of a successful acquisition bid by a consortium led by the Cerbens Capital Management, because the transaction was friendly 
own a majority of the stock of the resulting firm-the only majority ownership position on the list. This ownership state erodes the line distinguishing hedge fund from private equity investment and is not the only case of such an overlap in recent years. Hedge funds have emerged as bidders in competition with private equity firms in auctions of companies seeking to go private, and these cases have been excluded from the sample. ${ }^{58}$ The Kmart/Sears combination has been retained due to its legendary status as a successful hedge fund intervention to change a business plan. ${ }^{59}$ The strategy has been widely copied by other funds, resulting in the appearance of a number of targets in the sample. A taxonomic problem does remain and is dealt with by removing Kmart/Sears and the other friendly investments from the sample as appropriate.

\section{INVESTMENT POSITIONS}

This Section looks at the investments made by the hedge funds in the targets in the sample, breaking out aggregate figures by year of engagement, by the size of the target, and by the amount invested. The targets vary in size from the smallest of fry (RedEnvelope, with a market capitalization of $\$ 7.4$ million) to the biggest of fish (Time Warner, with a market capitalization of $\$ 74.1$ billion). Table I shows that, within the broad range, small firms dominate the sample, making up $61 \%$ of the targets. This confirms the conventional wisdom that hedge funds concentrate their attention on the small capitalization sector. ${ }^{60}$ But, as already noted, the sample could nonetheless understate their salience.

\begin{tabular}{|c|c|c|c|c|}
\hline $\begin{array}{c}\text { Table I: Target Market } \\
\text { Capitalization }\end{array}$ & Number & Percent & Mean & Median \\
\hline Large Cap (over $\$ 5$ billion) & 15 & 13 & $\$ 15.9$ billion & $\$ 11.2$ billion \\
\hline Mid Cap (\$1 to \$5 billion) & 30 & 26 & $\$ 2.5$ billion & $\$ 2.4$ billion \\
\hline $\begin{array}{c}\text { Small Cap (under } \$ 1 \\
\text { billion) }\end{array}$ & 69 & 61 & $\$ 281$ million & $\$ 172$ million \\
\hline
\end{tabular}

and Cerberus had made no prior equity investment in the target. See generally Albertsons Will Be Sold for $\$ 9.7$ Billion, N.Y. TMES, Jan. 24, 2006, at C2.

58. See Kishner \& Foster, supra note 35 , at 11 . At the same time, private equity funds lately have been acting more like hedge funds. They are "flipping" their investments more quickly. Blackstone Group lately bought a $4.5 \%$ stake in Deutsche Telekom, paralleling the investment pattern of the hedge funds. See Jason Singer, Raising the Stakes: In Twist for Private Buyouts, Some Shareholders Fight Back, Wall St. J., Aug. 18, 2006, at A1.

59. See generally Robert Berner, Eddie's Master Stroke: The Sears-Kmart Merger Creates a Retail Giant, Bus. WK., Nov. 29, 2004, at 34 (explaining the details of the Kmart/Sears merger).

60. Market capitalization is calculated (by refenence to the firm's Form $10-\mathrm{K}$ filed in the fiscal year ending prior to the first press report in the data sample) as follows: the average of the high and low stock prices for the year's last fiscal quarter multiplied by the number of shares outstanding at the end of the fiscal year. 
According to another story, hedge fund activism will rise in waves, resembling the leveraged restructuring movement of the 1980s. One round of successful intervention will lead to larger targets in the next round. Success will encourage new activist entrants, leading to more firms being selected as targets. Table II roughly confirms this story of a rising tide. As the column for 2003 shows, the tidal image comes more clearly into view if Kmart/Sears is omitted as a friendly anomaly. The level of activity reported in 2002 may come as a surprise. Activist intervention tends to be seen as a more recent phenomenon, but it turns out that hedge funds had been pushing managers for several years before the matter became the subject of policy discussions. Today's strategies add nothing material to those followed five or more years ago. ${ }^{61}$ The tide, as it were, already has risen.

\begin{tabular}{|l|c|c|r|r|r|}
\hline \multicolumn{1}{|c|}{$\begin{array}{c}\text { Table II: } \\
\text { Targets By Year }\end{array}$} & $\mathbf{2 0 0 2}$ & $\mathbf{2 0 0 3}$ & $\mathbf{2 0 0 4}$ & $\mathbf{2 0 0 5}$ & $\begin{array}{c}\text { 2006 } \\
\text { (six months) }\end{array}$ \\
\hline Number & 18 & 5 & 17 & 49 & 25 \\
\hline Mean target size (millions) & $\$ 699$ & $\begin{array}{c}\$ 3,307(\$ 496 \\
\text { without } \\
\text { Kmart/Sears) }\end{array}$ & $\$ 702$ & $\$ 4,186$ & $\$ 5,138$ \\
\hline Median target size (millions) & $\$ 58$ & $\begin{array}{c}\$ 895(\$ 473 \\
\text { without } \\
\text { Kmart/Sears) }\end{array}$ & $\$ 201$ & $\$ 1,074$ & $\$ 841$ \\
\hline
\end{tabular}

Cost helps to explain the dominance of small capitalization targets, while growing amounts of money under management help to explain the growth in the number of targets, particularly larger targets, over time. Larger targets call for a significant increase in financial commitment: The engagement's credibility increases with the percentage of voting shares held by, or allied with, the initiating activist; the larger the target, the smaller the percentage of shares bought by a set sum of money. Large numbers also make proxy contests more expensive. A credible threat accordingly presupposes a bigger fund. Unsurprisingly, then, the percentage of shares that a fund holds in a given target is negatively correlated $(-0.21)$ with the target's market capitalization. What most impresses about this statistic, however, is less the negative result than its small magnitude. Restating, in the $39 \%$ of the cases involving large- or midcapitalization firms, the hedge funds did not fully compensate for the larger numbers by reducing the proportion of outstanding shares purchased. Instead,

61. For examples of hedge fund strategies, see Steven Taub, Proxy Warriors, InstrTutional InvesTOR, Jan. 2003, at 51. See also Steven Taub, Over the Hedge, DaIly Deal, July 26, 2002 (noting the claim of Herb Denton of Providence Capital to have mooted sixteen opposition board slates over five years and placed twenty-two nominees on eleven boards). 
they stake materially greater sums. Table III breaks out median percentages of shares held by target size (omitting Kmart/Sears) and the median investment necessary to create the holding (median market capitalization of large-, midand small-capitalization targets times the percentage of stock held). It turns out that the larger targets implicate the lion's share of the capital at risk.

\begin{tabular}{|l|c|c|}
\hline \multicolumn{1}{|c|}{ Table III: Amounts Invested } & $\begin{array}{c}\text { Median } \\
\text { Percent Held }\end{array}$ & $\begin{array}{c}\text { Median } \\
\text { Investment }\end{array}$ \\
\hline Large Capitalization (Kmart/Sears omitted) & 6.7 & $\$ 753$ million \\
\hline Mid Capitalization & 8 & $\$ 194$ million \\
\hline Small Capitalization & 9.8 & $\$ 17$ million \\
\hline
\end{tabular}

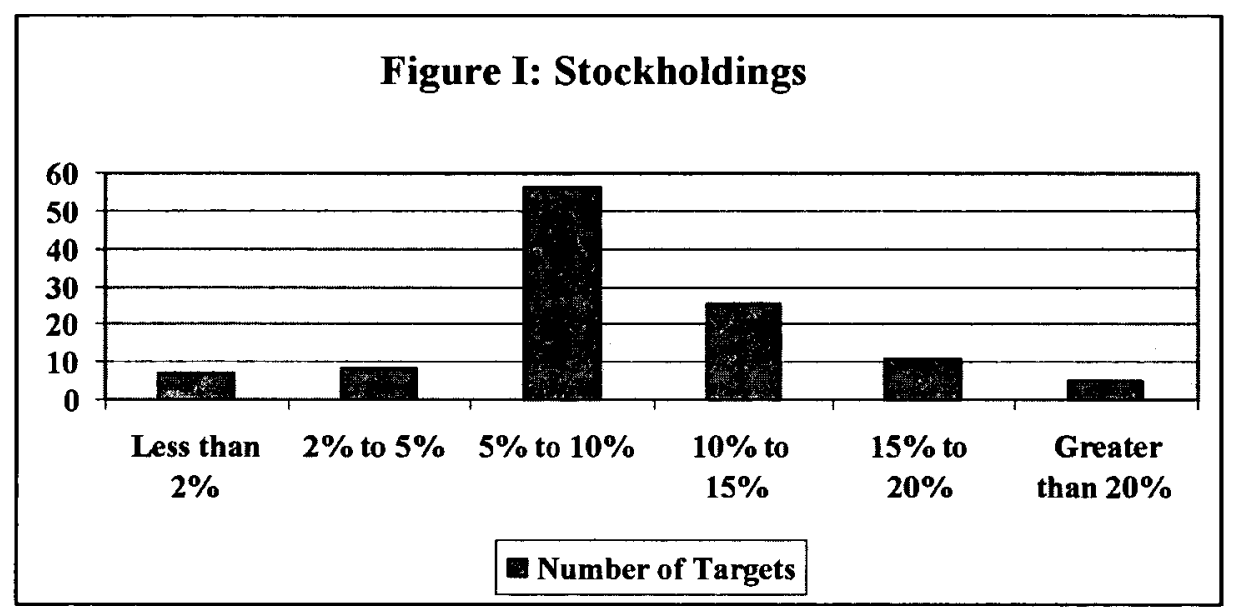

Why, assuming risk aversion even amongst hedge funds, do the large- and mid-capitalization engagements require these significant stakes of $6.7 \%$ and $8 \%$ of target stock? Figure I breaks down the funds' shareholdings by percentage magnitudes to show a notable clustering in the 5\% to $10 \%$ range. Few attempt an engagement holding only $1 \%$ of the stock, presumably because it takes a more substantial block to pose a credible threat.

Federal regulation explains the break at $10 \%$, the ownership level that triggers the short swing profit disgorgement and reporting requirements of section 16 of the Securities Exchange Act of $1934 .{ }^{62}$ Many of the positions between $10 \%$ and $20 \%$ follow from purchases made during the course of an

62. See 15 U.S.C. § 78p(a) (Supp. IV 2004); David Ikenberry \& Josef Lakonishok, Corporate Governance Through the Proxy Contest: Evidence and Implications, 66 J. Bus. 405, 413 (1993) 
engagement, after the filing of an initial 13D reporting a smaller number of shares. Such purchases signal an intent to hold on for at least six months. The five outliers with holdings above $20 \%$ all require specific explanation. The largest holding is Kmart/Sears (52.6\%). Two others, Pizza Inn (32.5\%) and SL Industries (28.6\%), are small, long-term holdings where the fund controls the target's board of directors. The other two, Register.com and PW Eagle represent groups of funds filing joint SEC reports. At the other extreme lie seven cases where the fund holds less than $2 \%$ of the stock. This group is disparate and not dominated by large capitalization targets. Cases where an activist with a small percentage position takes a run at a large firm tend to fall in the $2 \%$ to $5 \%$ range.

\section{TARGET CHARACTERISTICS}

Hedge fund activism calls for a two-sided explanation. One side, as we have seen, is institutional. We start with a large number of funds under pressure to produce double digit returns even as more money pours in. This incentivizes fund managers to extend existing strategies and pursue new ones-thus have the value funds evolved into activists. They did so in a post-scandal environment ${ }^{63}$ with a slowly recovering stock market, an environment that makes other institutional investors more inclined to be critical of managers, their strategies, and their governance practices. The other side of the explanation is financial. As value investors, the activists look for firms worth more than their present market price. As activists, they are not content to sit back and wait for the rest of the market to see the value and bid up the stock. They instead invest where they judge that their input by itself can cause the value to register.

There are three surprisingly easy ways an outside investor with influence can direct its input to get an immediate increase in return on investment. The investor either (1) gets the target to sell itself at a premium to a second firm, (2) gets the target to sell or spin off a significant asset, or (3) gets the target to pay out spare cash. There is also a fourth, more difficult way-the investor gets the target to change its long-term business plan for the better. The following looks at the set of targets through each of these four lenses.

\section{Sale}

In $33 \%$ (38) of the cases in the sample, the press reported the hedge fund's contention that the target should be sold. It is easy to see why the activists make this claim. In the U.S. merger market, companies are sold at a premium over market price that has averaged between 30 and $50 \%$ across the past three decades. ${ }^{64}$ But some firms make better candidates for sale than do others.

(reporting on a sample of ninety-seven proxy contests conducted between 1968 and 1987, and finding that the median challenger owned $10.6 \%$ of the stock). The hedge funds may be doing more with less.

63. See Shearer, supra note 15.

64. William W. Bratton, The Disappearing Disciplinary Merger 31 (June 2006) (unpublished manuscript, on file with author). 
Mergers occur in waves over time, ${ }^{65}$ and, within a given merger wave, activity tends to focus on specific industries. Activity within a given industry tends to cluster in a period of two or three years within a given wave, ${ }^{66}$ signalling deal-making pressure. ${ }^{67} \mathrm{~A}$ management experiencing such pressure makes an attractive target. The hedge funds look for smaller, weaker, underleveraged firms within a concentrated industry. ${ }^{68}$

The sample bears out these predictions. In a handful of cases, the target's managers themselves raised the red flag by cancelling a planned cash sale of the company (MaxWorldWide, Artesyn), or terminating a search process directed to a sale. In other cases, the company's managers initiated a sale process, going private process, or a private equity investment at a price deemed too low (Aspect Communications, Intercept, Bally, Stephan, Wells Financial, InfoUSA).

In still other cases, the activist looks for a firm amounting to a good prospect for sale in the market for going concern assets. The sample's time period commences during a trough in that market that extended from late 2000 into 2003.

A new merger wave started thereafter. It has since risen steadily around a number of focal point industries - energy, financial services, software and high technology products, commodity producers, health care, and real estate. ${ }^{69}$ Figure II divides the target sample into business sectors. The sectors caught up in the new merger wave are well represented, encompassing $49 \%$ of the targets. In these cases, the potential buyer is most likely a larger firm in the same industry. Private equity firms also are prominent buyers in the recent merger market, accounting for $14 \%$ of merger volume and focusing on smaller firms. ${ }^{70}$ Retail firms, including specialty stores and restaurants, have figured prominently in the private equity purchase pattern. ${ }^{71}$ They, not coincidentally, make up the largest target category in the sample.

65. Richard A. Brealy \& Stewart C. Myers, Principles of Corporate Finance 997 (5th ed. 1996) (describing this trend as one of the great mysteries of financial economics).

66. See Mark I. Mitchell \& J. Harold Mulherin, The Impact of Industry Shocks on Takeover and Restructuring Activity, 41 J. Fin. Econ. 193, 205 (1996).

67. For a confirming price study that shows that bidder returns are higher when the bid is less anticipated, see Moon H. Song \& Ralph A. Walkling, Anticipation, Acquisitions and Bidder Returns (Dice Center, Working Paper No. 2005-11, 2006), available at http://ssm.com/abstract $=698142$.

68. See Brent Shearer, Shareholder Revolt Snaps into Deal-Killer Mode, MERGERs \& AcQunstrions, Jan. 1, 2006. More particularly, a low ratio of enterprise value (EV) to earnings before interest, taxes, depreciation, and amortization (EBITDA) marks out a target. EV is market cap plus debt minus cash - the amount it would take to buy a firm and then pay off all of its obligations. EBITDA measures cash flows. A low ratio signals a company undervalued by the market with a good cash generating capacity. See Jack Hough, The Beauty of Ugly Stocks, SmartMoneY, Nov. 1, 2005, at 47.

69. See Dennis K. Berman, Year-End Review of Markets \& Finance 2005, Wall St. J., Jan. 3, 2006, at R3; Dennis K. Berman, Year-End Review of Markets \& Finance 2004, WALL ST. J., Jan. 3, 2005, at R10; Mark Cecil, First-Half M\&A: A Review of the Sordid Truth, MERGERS \& ACQuistions ReP., June 30, 2003.

70. See Dennis K. Berman, Stock Market Quarterly Review: Private-Equity Firms Dominate M\&A Deals; Sony-Led Group Pulls off MGM Win, As Corporations Mostly Stay Out of the Game, WALL ST. J., Oct. 1, 2004, at C13.

71. See Martin Sikora, A Diverse M\&A Landscape, Mergers \& Acquisitions, Feb. 2005, at 24. 


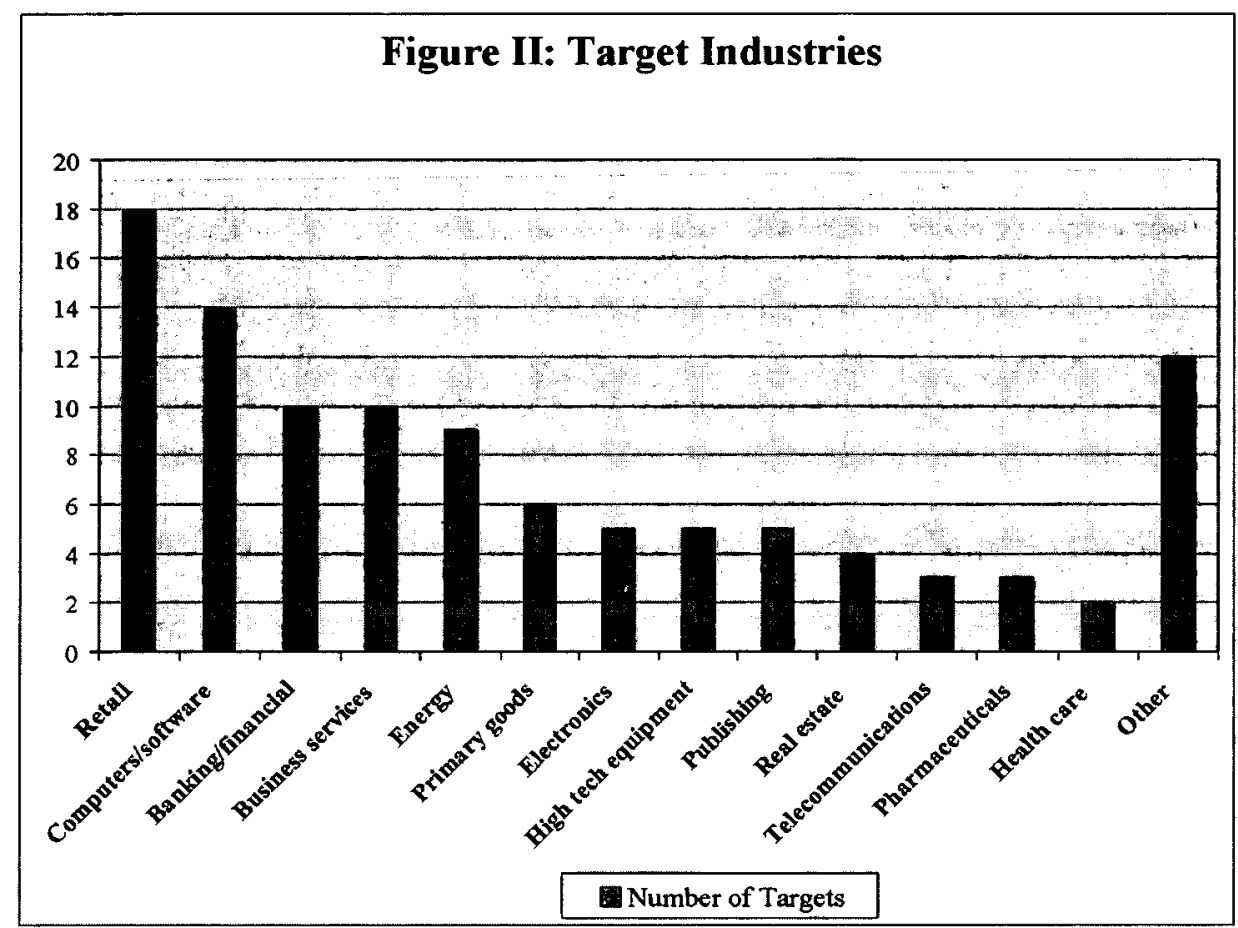

Finally, recall the case of Mylan. Just as the sale of a firm means a premium for its stockholders, so does the transaction's opposite party make the payment. If it pays too much, its stock falls. It follows that, as with Mylan, the announcement of an acquisition can be a red flag for activist intervention. Thus did five other firms on the list (Liquid Audio, Computer Horizons, Sovereign Bancorp, Spartan Stores, and Mirant) wake up to find themselves targets, and a sixth (Novt) attempt to escape a hedge fund challenge by making an acquisition only to have its shareholders vote down the deal.

\section{Unbundling}

Market intermediaries have been encouraging (or forcing) the unbundling of conglomerate firms for a quarter century. In their view, conglomerate mergers sacrifice value, a view supported by a stack of studies. ${ }^{72}$ The rule of thumb puts this "diversification discount" at $15 \% .{ }^{73}$ According to the prevailing explanation, the value loss stems from the conglomerate firm's ongoing overinvestment

72. See Raghuram Rajan, Henri Servaes \& Luigi Zingales, The Diversification Discount and Inefficient Investment, 55 J. Fin. 35, 36 (2000).

73. Philip G. Berger \& Eli Ofek, Diversification's Effect on Firm Value, 37 J. FIN. Econ. 39, 59-60 (1995). See generally Henri Servaes, The Value of Diversification During the Conglomerate Merger Wave, 51 J. Fin. 1201 (1996) (showing a loss in the 1960s and to a lesser extent in the 1970s). 
in the businesses of its unrelated subsidiaries ${ }^{74}$-the unrelated subsidiaries underperform only to be subsidized by better performing divisions. Unbundling, whether through a direct sale of the unrelated assets or their "spin off" into a separate publicly-traded firm, stops the flow of cash to poor performers. It also allows for better incentivized managers and imports transparency, facilitating monitoring by the board. ${ }^{75}$ Under an alternative line of explanation, the discount stems from defects in stock market pricing rather than agency costs and governance shortcomings. More particularly, the expected future returns of diversified firms are different from those of single purpose firms ${ }^{76}$ The diversified firms' different expected returns dictate a higher discount rate. The "diversification discount" follows from the use of a higher discount rate.

A hedge fund will appreciate a $15 \%$ discount without necessarily caring much about its source because unbundling the unrelated or underperforming asset can be expected to increase the stock price. In $32 \%$ (36) of the cases in the sample, the hedge fund was reported at the outset as contending that the target should sell or spin off specified assets. Significantly, such a target need not be a conglomerate encompassing unrelated lines of business. A multidivisional firm in one industry can have an underperforming division that the others support, so that the division's sale or spin off will make up a discount. Indeed, the division need not be a poor performer in order for the target's stock to be discounted: if an unessential division can be sold into the market for going concern assets at a premium unreflected in the ex ante stock price, the premium's realization enhances shareholder value (if not productivity). Thus do the activists look for firms that recently have closed acquisitions within their own industries, ${ }^{77}$ ready to suggest that they sell their purchases and direct the proceeds into the shareholders' pockets through a special dividend or share repurchase. ${ }^{78}$ Finally, targets can sell other assets, particularly unessential real estate. The activists have pushed such sales at many targets in the retail and forest products businesses-Kmart/Sears, Potlatch, McDonalds, Bally, Circuit City, OfficeMax, Weyerhaeuser, CKE, CBRL, and OSI. Note that real estate can be "unessential" even if the going concern still needs the premises situated thereon-the land can

74. See Philip G. Berger \& Eli Ofek, Bustup Takeovers of Value-Destroying Diversified Firms, 51 J. FIN. 1175, 1176 (1996). See generally Rajan, Servaes \& Zingales, supra note 72 (finding that internal capital markets in conglomerates transfer funds across divisions in an inefficient manner in a Tobin's $q$ based study).

75. Berger \& Ofek, supra note 74, at 1176 . In addition, the top team's management skills may be better suited to the firm's core assets than to the unrelated divisions. See Lane Daly, Vikas Mehrotra \& Ranjini Sivakumar, Corporate Focus and Value Creation: Evidence from Spinoffs, 45 J. FiN. EcoN. 257, 259 (1997).

76. Owen A. Lamont \& Christopher Polk, The Diversification Discount: Cash Flows Versus Returns, 56 J. Fin. 1693, 1699-1705 (2001) (showing higher required returns for diversified firms).

77. See Taub, Proxy Warriors, supra note 61 (describing Jeffrey Ubben's attraction to "roll ups").

78. See William W. Bratton, The New Dividend Puzzle, 93 GEo. L.J. 845, 849-52 (2005) (describing payout practice). 
be sold and leased back with the proceeds going out the shareholders. ${ }^{79}$ With recent real estate prices at an apparent cyclical high while stock prices have languished, the exercise makes perfect financial sense, at least from the point of view of the shareholders.

\section{Cash}

With sale, whether of the whole or a part, the idea is to turn a going concern investment into present cash. It follows that the best of all targets is a firm sitting on a lot of cash already, or at least an amount in excess of the amount needed to operate the business. Paying out such cash also makes perfect financial sense. Corporations tend to put such funds into safe short term investments; given the low interest rates prevailing today, such investments yield below the market return on the corporation's stock.

Cash rich firms existed in record numbers in 2006. The cash accounts of nonfinancial firms held a record $\$ 1.5$ trillion, double the amount of seven years earlier. ${ }^{80}$ This amounted to $40 \%$ of the long-term debt of the firms in the S\&P 500 , a ratio close to a record. Compared to their stock market value, the S\&P 500 's cash accounts stood at the highest point since the early 1980s. ${ }^{81}$ There are a number of explanations. Firstly, the economy had been expanding and corporate earnings had grown with it. At the same time, managers had not been spending heavily on capital investment or raising their employees' salaries. Indeed, shell-shocked by the 2001-2003 recession, they continued to cut operating costs and to refinance in order to take advantage of low interest rates, both of which enhanced cash yields. ${ }^{82}$ Although cash payouts to shareholders also increased, they did not do so fast enough to deplete corporate holdings. ${ }^{83}$

There resulted a classic conflict of interest between the shareholder interest, on the one hand, and management and inside constituents, on the other. Holding onto the cash enhances management's freedom of action and insulates the firm from adverse economic shocks. To the shareholders, however, it is free cash flow-cash in excess of the businesses' needs that ought to be paid out. Free cash flow was an issue two decades ago, when shareholders charged that managers retained the cash to invest in suboptimal projects. ${ }^{84}$ Today the situation is slightly different. Even as levels of cash match those of two decades ago, management cannot be accused of suboptimal reinvestment. Management has, to that extent, internalized the lessons of the 1980s. Instead, it simply holds the

79. See Sarah E. Lockyer, CKE Latest Target in Growing Trend of Activism, NATION's RestaURANT NEws, Feb. 29, 2006.

80. Farzad, supra note 37 , at 66 .

81. Shearer, supra note 15.

82. Moreover, prior to 2005 , firms were not using their spare cash as currency to make acquisitions. See Ian McDonald, Awash in Cash: Cheap Money, Growing Risks, WALl St. J., Nov. 28, 2005, at A1.

83. Id. In 2005, the S\&P 500 dividend yield was only $1.8 \%$; sixty of the firms in the index reduced their shares outstanding by $4 \%$ through repurchases. Id.

84. Michael C. Jensen, Agency Costs, Free Cash Flow, Corporate Finance, and Takeovers, 76 AM. Econ. Rev. PAPERS \& Proc. 323, 323-24 (1986). 
cash in short term investments. From a shareholder value point of view, this is an improvement, but not a cure. Meanwhile, the number of potential targets grows with the cash accounts.

Cash rich firms show up prominently in the sample. To test for cash, eight firms were removed from the sample-the six banks and two investments in distressed firms (Adelphia and Footstar). Ratios of cash and cash equivalents to total assets, and of cash and cash equivalents to short term borrowing and funded debt ${ }^{85}$ were drawn from the remaining 107 firms' balance sheets for the fiscal year preceding activist engagement. "Cash rich" is defined as a cash to total assets ratio of 0.15 or greater plus a cash to debt ratio of 0.50 or greater. By this metric, $38 \%$ of the firms are cash rich. An additional $4 \%$ of the firms meet the cash to debt leg of the test but not the cash to assets leg; one firm (Mirant) just misses both legs of the test.

The recent rise in corporate cash balances implies growing numbers of cash rich targets over time. Figure III, however, shows the opposite to have been the case within the sample. The yearly percentage of cash rich targets stays stable from 2002 to 2004 , ranging between $56 \%$ and $60 \%$, and then declines to $31 \%$ in 2005 and $22 \%$ in 2006. Median cash to debt ratios and cash to asset ratios decline similarly: cash to debt goes down from 7 in 2002 to 0.2 in 2006; median cash to assets goes down from 0.2 in 2002 to 0.03 in 2006.

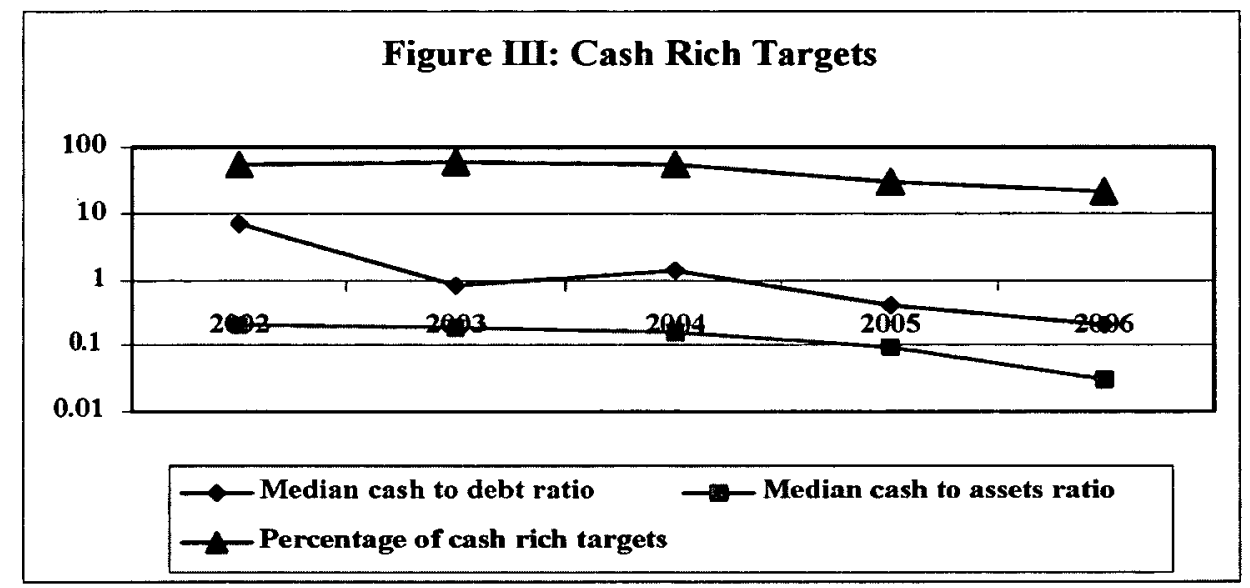

The results imply that the activists grabbed low-hanging fruit in the first three years, searching thereafter among a depleted stock of prime targets. Further extrapolation lets us predict an adverse selection problem. As more money flows into more funds pursuing double-digit gains from activist strategies, the funds relax their financial standards, pursuing less appropriate targets. Extending the projection one more step, fund returns decline, and the activist wave of

85. Including the current portion of funded debt. 
2005-2006 subsides over time. The last projection implies a warning: Activists gaining influence over the managers of firms holding out less immediate value will resort to high risk, high return strategies, replicating the pattern of the high leveraged restructurings of the late 1980s. The economy will be left to pick up the deadweight cost of the resulting financial distress.

Such projections are easy to make. But nothing in the financial profiles of the firms in the sample dictates that we do so. The sample's early engagements did indeed include low hanging fruit. Several were firms that had raised cash in the 1990s tech stock market only to find themselves with nowhere to invest it after the crash (Liquid Audio, MaxWorldWide, and MeVC Fund). It also is true that later targets have more debt and less cash. But the palette of value strategies has broadened. A lucrative real estate sale, for example, calls for no preexisting cash horde. We will return to this matter in Part III when looking at the record of cash payouts made by the target group.

\section{Good Assets, Bad Managers}

Activist engagements always start with a bill of particulars describing the target's shortcomings. The bill, in turn, always starts by stating that the target's stock is undervalued, perhaps also citing recent earnings reverses. The activist, as we have seen, then often recommends sale of the whole or a part or disgorgement of uninvested cash. In many cases, however, the activist makes a more particular critique of the target's managers and business plan. The usual allegation is excessive cost. With an energy firm, this means exploration costs. With a technology firm, this means research and development (R\&D). With other firms, this means selling, general, and administrative expenses (SG\&A)the costs of running the business (advertising, salaries, fringe benefits, and perquisites of the managers at headquarters) in addition to the costs of goods sold. $^{86}$

These interventions raise questions respecting the activists' standing as critics and their allegations' credibility. Making the allegation is not rocket science. All one has to do is to take out the target's income statement, highlight a cost line, check the comparables for lower numbers, and assert that the amount should be lower. Executing a cost cutting program without impairing the firm's production function is another thing entirely. Doing so presupposes a significant investment in knowledge of the business and a long-term investment commitmentproperties historically more characteristic of private equity firms than hedge funds. But many activists appear ready to make these commitments. They employ industry experts to make diagnoses, they serve on their targets' boards

86. According to one analyst, if the firm's product does not require a large advertising budget, SG\&A should be around $40 \%$ of gross profits; for a heavy advertiser, $60 \%$; but if SG\&A is $80 \%$, costs can be cut. See Hough, supra note 68, at 47 . In a few cases in the sample, the activists also highlighted right-side shortcomings-in particular new equity financing, whether through an issue of new common stock or convertible debt. The reason is evident-new equity dilutes, depressing the stock's value. If new financing is necessary, the money should be borrowed, raising the rate of return on the stock. 
of directors, and, when they get into control positions, they employ experienced managers to run the targets. ${ }^{87}$

The "good assets, bad managers" complaint extends to the targets' governance processes. Items on standard poor governance checklists show up prominently on activist bills of particulars-poison pills, staggered boards, lack of director independence, and excessive stock options or other flawed incentive compensation. The activists put these items at the front and center of their complaints. But, at the same time, there is no case in the sample in which governance objections stand alone as the explanation for the intervention. Hedge fund activism is about value; governance and the processes of capital market discipline take second place on the agenda. Governance and process also play a tactical role. The credibility of an activist's threat depends on its plausibility within the wider community of institutional investors, and a showing of poor target governance practice enhances the case's appeal.

\section{E. TARGET PERFORMANCE}

According to classic agency theory, problems of opportunism and adverse selection among managers generate "agency costs" that impair corporate performance. ${ }^{88}$ Two points follow. First, high agency cost firms will underperform in the stock market relative to low agency cost firms. Second, governance intervention that reduces agency costs will improve performance and, thus, is justified. The theory triggers a question respecting the activist hedge funds and their selection of targets: whether the targets underperform as compared to other firms in their industries or the stock market as a whole.

Significantly, nothing in agency theory dictates an affirmative reply in this case. Activists intervene because they see a chance to realize value in the near future. Poor performance certainly can create such an opportunity, but so can past success. A firm sitting on a large cash account may thereby have a low return on equity and underperform relative to its peers, but cash by itself does not dictate that conclusion. Indeed, the cash may be there because the firm has an outstanding management team that runs a tight ship. The same goes for a target seen as a prospective acquisition candidate, or a target with saleable assets. When Pershing Square's William Ackman took on McDonald's in 2005-2006 with an elaborate plan looking toward a sale of the real estate underneath its company-owned franchises, he could not deny that the company's CEO had just executed a brilliant turnaround. ${ }^{89}$ Similarly, the hedge funds that forced an auction of Beverly Enterprises acknowledged that management had done an excellent job and that its business plan remained plausible. But the funds professed no interest in waiting around for the promised growth's realiza-

87. See Kishner \& Foster, supra note 35.

88. Michael C. Jensen \& William H. Meckling, Theory of the Firm: Managerial Behavior, Agency Costs and Ownership Structure, 3 J. Fin. Econ. 305 (1976).

89. See Authers, supra note 25, at 14. 
tion..$^{90}$ Success can make a firm like Beverly even more vulnerable to attack. As its stock appreciates, long-term holders trade out and take their gains, leaving a more volatile, less satisfied stockholder population behind them. ${ }^{91}$

Nor need red flags of poor governance like poison pills and staggered boards mean underperformance, even as they have been shown statistically to tend in that direction. ${ }^{92}$ Consider Sovereign Bancorp, a firm in the sample that stands out for poor governance. Its imperial CEO, Jay Sidhu, triggered an activist challenge by bringing in a friendly $20 \%$ blockholder and simultaneously using the proceeds of its equity investment to make a questionable acquisition. ${ }^{93}$ The activist had every reason to intervene, but past performance may not have been one of them. Sovereign had outperformed its industry by $40 \%$ over the preceding three years, at least according to its 2005 proxy statement. ${ }^{94}$

Why should positive past performance matter if the activist can put value on the table? To answer, let us draw on the team production theory of the firm. ${ }^{95}$ This suggests that value-creation in organizations presupposes a stable and cooperative environment. Outside attack impairs the environment, holding out costs that need to be weighed against the benefits of short-term value-creation for the shareholders' benefit. The costs loom less large when the firm is a poor performer-instability may even carry benefits in such a case. Where the firm is a good performer, instability not only may impair its performance, it also may inhibit economic commitment at comparable firms.

Agency theory, then, suggests that poor performers make the most likely targets, while team production theory suggests that they make the most appropriate targets. The SEC filings of the firms in the sample were consulted to see if poor performers predominate. The SEC requires reporting firms to report in their annual proxy statements on their stocks' performance against industry and market portfolios for the preceding five years. ${ }^{96}$ Reported figures were collected for 104 of the firms in the sample from the proxy statement immediately preceding the engagement's onset (the remaining ten firms either failed to comply, or failed to convene annual meetings). Figure IV sets out the percentages of underperforming firms in the sample, grouped by the year of the engagement's commencement. A trend emerges-fewer underperformers show

90. See Phyllis Plitch, Companies Cut Deals To Sidestep Coup Attempts by Antsy Investors, WALL ST. J., Aug. 10, 2005, at B3.

91. See David A. Katz \& Laura A. McIntosh, Advice on Coping with Hedge Fund Activism, 235 N.Y. L.J. 5 (2006).

92. See Paul A. Gompers, Joy L. Ishii \& Andrew Metrick, Corporate Governance and Equity Prices, 118 Q.J. ECON. 107, 121-25 (2003).

93. See, e.g., John Dizard, Shareholders' Blood is up over Sovereign and Calpine, Fin. TIMES (London), Dec. 13, 2005, at 12.

94. Sovereign Bancorp, Definitive Proxy Statement (Schedule 14A), at 38 (March 22, 2005).

95. See, e.g., Margaret M. Blair \& Lynn A. Stout, A Team Production Theory of Corporate Law, 85 VA. L. REv. 247, 274-81 (1999) (describing a hierarchical governance structure suited to encouraging firm-specific investment and team cooperation).

96. See Schedule 14A, item 8; Regulation S-K, item 402(l). 
up in the sample across time. The trend is particularly noticeable in the industry index comparison-in the early years, four-fifths of the targets underperformed their industries; in the more recent three years, most of the targets were over performers. The market yardstick also signals improvement in target quality, albeit less starkly.

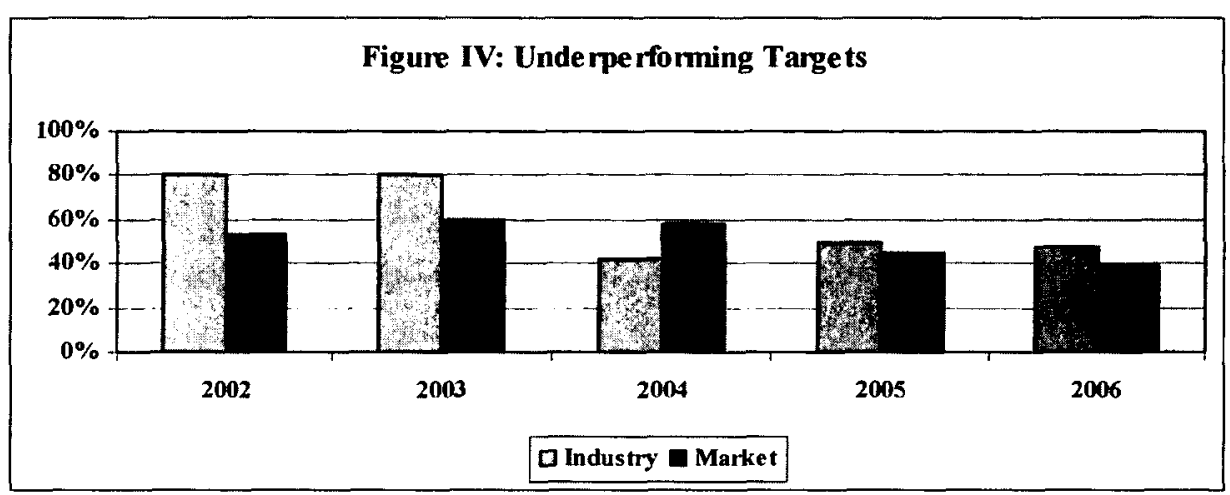

The overall impression is one of a fifty-fifty split between underperformers and overperformers. To test this further, percentage measurements of underperformance or overperformance were constructed for each firm's stock price against the industry index. Two classes of targets were removed from the sample at this point - the friendly engagements, in case of a skew either way, and two cases of investment in a distressed target (Adelphia and Footstar). Figure $\mathrm{V}$ shows median and mean results for (a) the entire sample, (b) by year: 2002-2006, and (c) by size: large, mid, and small capitalization. The mean figures are negative across the board, reflecting the presence of many extreme cases in the underperforming group. The medians reflect the lesson of Figure IV - that the sample is roughly split between underperformers and overperformers, with the early years being more weighted toward underperformance. A median/mean comparison makes a third point-the over-performing companies contain relatively few examples of notable success. Finally, a distinction can be drawn between the large and mid capitalization firms and the small capitalization firms: The two subsets of larger targets are relatively free of catastrophic failures, reflecting the basic financial point that larger firms hold out less risk. 


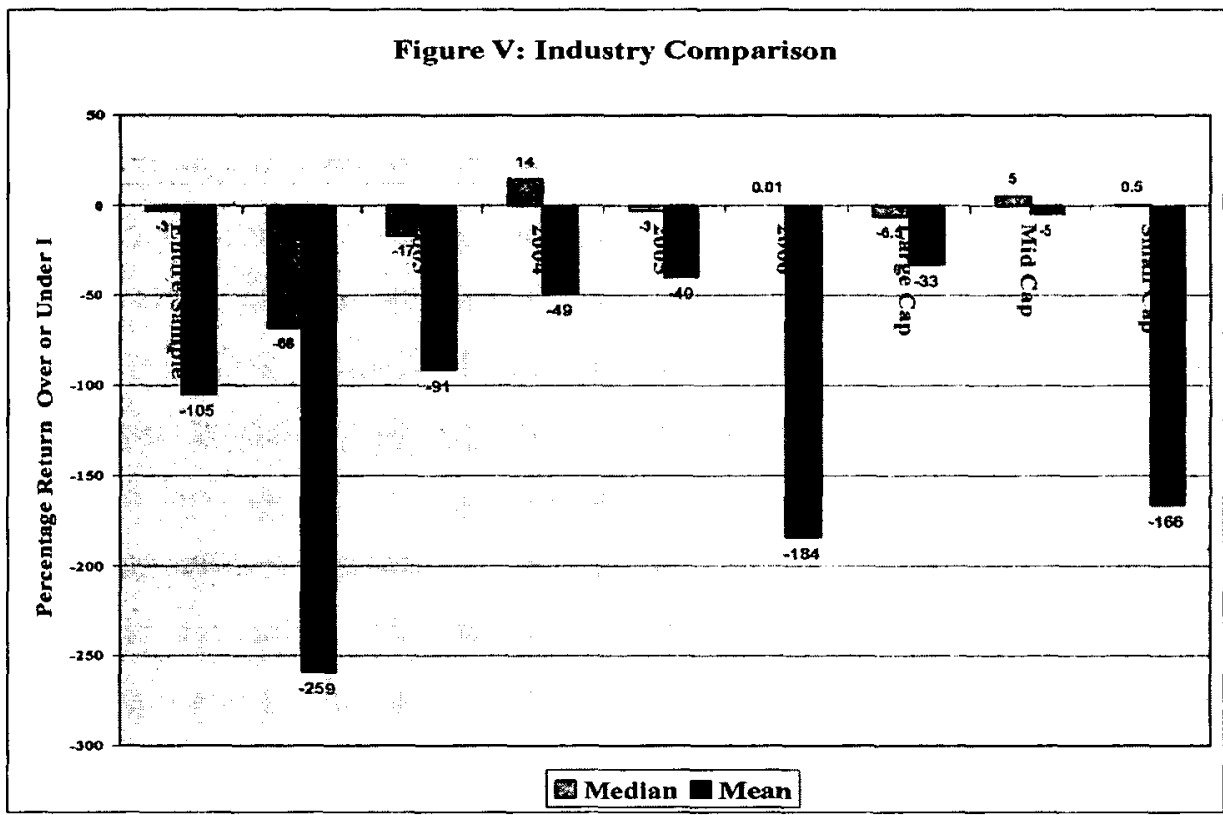

Figure VI offers the same analysis of the targets' performance against market indices. The means once again show that large-magnitude outliers show up on the downside. But the medians more clearly show the shift toward better performers after 2003. They also confirm the separation between the small capitalization targets, on the one hand, and mid and large capitalization targets, on the other, with the former more pronounced in its selection of underperformers. The $-140 \%$ mean result for the large-capitalization sector stems entirely from two targets-the long-lagging Time Warner and just-out-of-Chapter 11 Mirant.

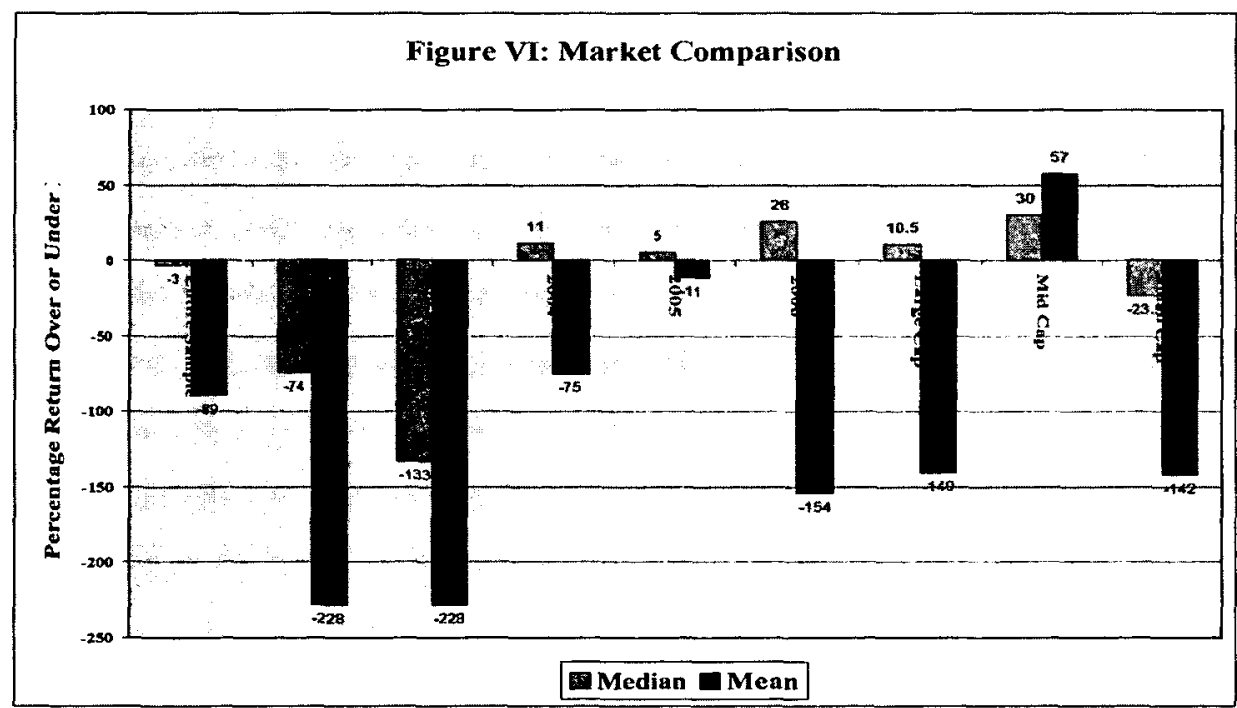


Now to the question whether the data confirm or falsify the agency prediction that activists will target underperforming firms. The proposition is neither falsified nor confirmed. On a per capita basis, neither type notably dominates the sample after 2003. At the same time, underperformance in the stock market clearly attracts the activists. This outcome makes sense: Given equal value on offer, a long-term failure makes a better target than does a reasonable performer, because the failure has a more dissatisfied group of shareholders.

Finally, note that empirical tests of takeover targets tend to show no systematic underperformance by either industry or market measures. ${ }^{97}$ The comparison is interesting. From both agency and team production points of view, the hedge funds may be more discriminating in their target choice than are bidders in the market for corporate control. Contrariwise, the large numbers of positive performers in the group assure that many observers will see hedge fund activism as problematic from a policy point of view.

\section{F. SUMMARY}

Activist hedge funds look for four things in their targets-potential sale of the whole, potential sale of a part, free cash, and cuttable costs. Given one or more of those factors, poor performance makes for a better target. The sample implies some depletion in the stock of prime targets over time. But, as we also have seen, the number of interventions continues to increase. Given value on offer, positive results do not assure repose in today's boardrooms. Conversely, the bigger the target, the higher the level of difficulty and the greater the financial risk for the activist. But the deterrent effect of size has diminished over time. Today, no board of directors is immune from challenge.

\section{Strategies, Outcomes, AND the Balance of Power}

This Part describes the record of engagement between the sample's hedge funds and targets. The salient strategic device is the proxy contest, whether waged in fact or merely threatened. The outcomes range between two clear-cut end points. On the win side lies sale of the target at a premium as the result of the intervention, while on the loss side lies hedge fund withdrawal without concessions from the target. Between these termination points lie varying levels of success. This success can come in the form of direct governance participation on the target board or indirect input through a back-and-forth process of pressure and concession. Closer to the loss side lies continued management resistance under pressure. Overall, the activists have had a high rate of success.

Section A describes the pattern of engagement, drawing on quantitative results from the sample. Section B sets out the governance outcomes of the cases in the sample.

97. See Bratton, supra note 64 , at 5-12 (summarizing the studies). 


\section{A. PATTERNS OF ENGAGEMENT}

The typical sequence of events can be divided into two stages. First comes initial contact, when the activist reveals itself and the target decides whether to cooperate or resist. Resistance ushers in the second stage, during which the activist pursues its strategy of attack. There are two possible outcomes: either the activist gets what it wants, or it abandons the engagement and sells the stock. The latter result does not occur very often in the sample, however. The activists tend not to take no for an answer, and keep their campaigns going until they get a yes.

\section{Initial Engagement}

Engagements between activists and targets start with a letter and a follow-up call, usually occurring just prior to the filing of a Schedule 13D that makes public the fund's ownership of 5\% or more of the target's stock. The letter (and the call, if taken) tells the target that it is undervalued and outlines steps that the fund recommends to realize value for the shareholders in the near future. The fund then asks for a meeting.

Target management has two choices at this point. It can take the call and convene a meeting, looking toward a back-and-forth in which it defends its business plan and attempts to persuade the fund to take a passive, patient view of its investment. Alternatively, it can refuse to engage; many targets have made this choice. The immediate result of refusal is often a public rebuke in the fund's first 13D filing. The rebuke will be addressed to the target shareholders, telling them that the fund has made constructive suggestions that the managers have ignored. Subsequent correspondence with the target likewise goes into the SEC file, which serves as the de facto press room in the fund's campaign. Where, as with the cases in the sample here, the business press takes an interest in the matter, a new filing can prompt a new round of reports.

Consultants who market themselves as defensive advisors to managers coping with activist interveners stress the initial stage's importance. They recommend engagement with the goal of inducing more moderate responses. They also recommend advance planning-managers should be ready with a persuasive analysis that defends the business plan and, if possible, counters value claims made by the fund. ${ }^{98}$ The more effectively a target has communicated the case for its business plan to the investment community prior to the engagement, the stronger the target's position in the negotiation. ${ }^{99}$ Even better, say the consultants, the firm should avoid being a target in the first place, anticipating the activists by remitting excess cash to the shareholders and actively monitoring and managing its mix of businesses. ${ }^{100}$ The consultants offer good advice. Even so, there is no case in the sample where an early meeting leads a hedge

98. See Katz \& McIntosh, supra note 91, at 5.

99. Preparing for and Pre-empting Hedge Fund Activism, Investment Dealers' Dig., May 29, 2006. 100. Id. 
fund to abandon a publicized value maximization plan and accept the target's existing approach. ${ }^{101}$

By contrast, in $18 \%$ of the hostile cases, the engagement never gets past the initial stage, with the fund's public presence alone inducing target management to make concessions. The wolf pack effect contributes to such decisions. ${ }^{102}$ The 13D filing sends a signal to other funds who take positions in the target stock. ${ }^{103}$ The target sees little chance of victory in a contest fought to the finish and so either comes to the table and settles or preemptively takes an action recommended by the activist. These initial stage concessions encompass a wide range of outcomes. On the minimal end, the concession implies no commitment-for example, the target engages an investment banker to look into value-creating alternatives or it appoints an additional independent director from the financial sector. More concrete initial stage concessions come in the form of asset sales and cash payouts. Even the ultimate concession-the sale of the companyoccurred at the early stage when Knight-Ridder sold itself in $2006 .{ }^{104}$ In still other cases, the target makes a process commitment to the activist's agenda by conceding to it one or more seats on the board of directors. Thus did Jerome York join the General Motors board as Kirk Kerkorian's designee. ${ }^{105}$

\section{Target Resistance, Hedge Fund Attack}

In the more usual case, the target rejects the fund's proposals, sometimes with a peremptory announcement and sometimes after a formal meeting. The activist typically responds by threatening a proxy fight. The threat moves the engagement to the next stage. The activist has the choice of making good on the threat and incurring the expense of proxy solicitation, or of sitting back, keeping up the pressure, and waiting for concessions. The latter route appears to be preferred. Although a proxy contest at a small firm can cost as little as $\$ 100,000$, the average cost ranges between $\$ 250,000$ and $\$ 1$ million. ${ }^{106}$

Meanwhile, the line separating a proxy threat from a proxy contest is not very

101. There are three cases in the friendly subset (Heidrick \& Struggles, Unisource, and Reynolds and Reynolds) where early meetings were held. However, there is no evidence that the meetings led to the friendly stances.

102. Wolf pack behavior lends itself to the charge that the participating funds constitute a "group" for securities law purposes and hence should jointly file a 13D. The courts have not been receptive to this claim, however. See Hallwood Realty Partners v. Gotham Partners, 286 F.3d 613, 616-18 (2d Cir. 2002) (affirming district court's finding that plaintiffs' evidence of communication among three funds in question was insufficient to establish a group).

103. See Phyllis Plitch, Lawyers See No Poison Pill To Feed Hedge Fund "Wolf Packs," Dow Jones Newswires, Dec. 15, 2005 (describing wolf pack power and the absence of effective defenses); Katz \& McIntosh, supra note 91 , at 5 (stressing the importance of initial contact with the hedge fund).

104. For the result, see Knight Ridder Inc., Current Report (Form 8-K) (Mar. 14, 2006).

105. See General Motors, Announcement of New Board Member (Form 8-K) (Feb. 6, 2006).

106. See Marietta Cauchi, Activist Hedge Fund Strategy Gaining More Adherents, Dow JonEs News SERVICE, Feb. 6, 2006. 
clear under today's liberalized SEC proxy rules. ${ }^{107}$ An activist that has "threatened" a proxy contest to no effect often follows up by announcing its "intent to solicit" proxies. This raises the stakes, but not necessarily by much. Such an announcement can occur nine or ten months prior to the annual meeting and implies no commitment to proceed. It does entail a shift in the pattern of SEC compliance-correspondence, statements, and reports previously filed under $13 \mathrm{D}$ now also go in as preliminary $14 \mathrm{~A}$ solicitation materials. The filings, which can include outside expert analysis of the target and its business, get reported in the press, and the pressure intensifies. ${ }^{108}$

\begin{tabular}{|c|c|c|c|c|c|c|}
\hline \multicolumn{7}{|c|}{ Table IV: Proxy Contests (number of cases) } \\
\hline $\begin{array}{c}\text { No threat } \\
\text { of proxy } \\
\text { contest }\end{array}$ & $\begin{array}{c}\text { Threat } \\
\text { without } \\
\text { initiation }\end{array}$ & $\begin{array}{c}\text { Contest initiated } \\
\text { ("intent to } \\
\text { solicit") }\end{array}$ & $\begin{array}{c}\text { Extended } \\
\text { campaigns }\end{array}$ & $\begin{array}{c}\text { Board } \\
\text { election via } \\
\text { proxy }\end{array}$ & $\begin{array}{c}\text { Proxy } \\
\text { contest } \\
\text { fails }\end{array}$ & $\begin{array}{c}\text { Contest } \\
\text { pending }\end{array}$ \\
\hline 24 & 17 & 60 & 13 & 19 & 7 & 2 \\
\hline
\end{tabular}

The activist's statement of intent to solicit, while manifestly made in the hope of never getting to the point of filing and distributing a definitive proxy statement, nonetheless is credible. The activists, faced with a recalcitrant target, do make good on their threats and solicit. They also demonstrate their commitment and tenacity when defending managers resort to standard subterfuges like delaying the annual meeting, increasing the number of directors, or amending the by-laws to impose new requirements on contestants. The funds go to court in response-such litigation occurred in sixteen of the cases.

Activist tenacity is particularly evident in thirteen campaigns extending for more than one year. Typically, the fund accepts a minor concession, say, as in the case of Topps, agreeing to hire an investment banker to look into value alternatives. When this process leads to nothing, the fund proceeds with a proxy fight in a subsequent year. In the case of RedEnvelope, the campaign has been going on for three years, involving a proxy loss in 2004, a win along with management concessions in 2005, and another pending contest in 2006. Santa Monica Partners, a persistent activist against Warwick Valley Telephone, lost an issue-based proxy solicitation but kept the campaign going anyway. The target

107. See 17 C.F.R. $\$ 240.14 a-12$ (2006) (permitting communications prior to filing of proxy card so long as they are filed with the SEC and make specified disclosures). The activists also take advantage of the short slate provision, 17 C.F.R. $\$ 240.14 a-4$ (d) (2006), to run fewer candidates than the number of seats up for election. For a discussion of the change in the regulatory environment, see Thomas $\mathrm{W}$. Briggs, Corporate Governance and the New Hedge Fund Activism: An Empirical Analysis, 32 J. CoRP. L. (forthcoming 2007) (manuscript at 7-13, on file with author), available at http://ssrn.com/ abstract $=911072$.

108. There are also three "just vote no" cases and one meeting boycott to prevent the target from getting a quorum. One of these cases is pending (New York Times). None of the other three (Stilwell Financial, Houston Exploration, NABI Pharmaceuticals) managed to prevent the target from taking action, but do not appear to have negatively impacted otherwise successful campaigns. 
made the concession of hiring an investment banker, but Santa Monica pushed harder and ran a board slate. It lost again, but does not appear to have retreated. ${ }^{109}$

Once a proxy contest ripens into a bona fide solicitation, many target managers settle after running a preliminary vote count and getting bad news. ${ }^{110}$ A small number of contests have gone to the count. The activists have garnered board seats in nineteen of these. Management has won a solicitation in seven cases, two of them issue-based and five involving dissident board slates. ${ }^{111}$ Just looking at the contests for board seats, this outcome means a $79 \%$ success rate. This figure compares with a 52\% success rate derived by lkenberry and Lakonishok for a sample of ninety-seven board contests between 1968 and 1987. ${ }^{112}$ By historical standards, then, the hedge funds are doing well.

An inquiry into subsequent events in the seven losing cases shows them to be doing better still. In only one (Aspect Communications) did the fund accept defeat and withdraw. In another (Vista Bancorp), the target soon turned around and sold itself, fulfilling the activist's objective. In a third (RedEnvelope), the activist came back a year later to win a seat on the board. A two-time target (Warwick Valley Telephone) did at least hire an investment banker. The activist campaign against it remains open, as it does respecting the two remaining targets in this group (InfoUSA and Astoria Financial), making the final outcomes uncertain. Results in "initiated" proxy contests also are pending in another two cases.

\section{B. OUTCOMES}

Table $\mathrm{V}$ sets out results respecting the targets in the hostile sample, as of December 31,2006 . Each case is assigned one outcome; for cases involving ongoing campaigns with multiple results over time, the figures reflect the most recent event in the case. Table $\mathrm{V}$ arranges the outcomes to highlight the cases' process characteristics, breaking out three categories-settlement, pressure, and full-dress proxy contest. A "settlement" implies an arrangement concluded as the result of negotiations between the activist and the target. These tend to accompany the initiation of a proxy fight. Concessions resulting from "pressure," in contrast, do not stem from face-to-face agreements and often occur as the target's unilateral action, at least when viewed from outside. Together these cases make up $67 \%$ of the sample and $80 \%$ of the group of

109. See Chris Nolter, Rural Telecoms Draw Hedge Funds, TheDeal.com, July 3, 2006.

110. This happened in ten of the sixteen full-blown contests (whether or not involving hedge fund proponents) that occurred in 2005. See Plitch, supra note 90.

111. Institutional Shareholder Services often recommends votes for the dissident slate (for example, Exar and Nautica) but also has sided with management in other cases (for example, MeVC, Warwick Valley Telephone, Aspect). For a compilation of ISS advice respecting proxy contests between hedge funds and targets, see Briggs, supra note 107, at A-1 to -3.

112. See Ikenberry \& Lakonishok, supra note 62 , at 413-14. Too much should not be made of the comparison of success rates, however. The Ikenberry and Lakonishok numbers date from the era before the proxy rules facilitated nonmanagement solicitations for fewer than all seats up for election; the level of difficulty was correspondingly higher. 
successes. The class of proxy contest victories makes up $17 \%$ of the sample and $20 \%$ of the successful group.

\begin{tabular}{|c|c|c|c|c|}
\hline \multicolumn{5}{|c|}{ Table V: Outcomes (percent of the hostile sample) } \\
\hline $\begin{array}{c}\text { Settlement: } \\
\text { Board } \\
\text { seat }\end{array}$ & $\begin{array}{c}\text { Settlement: } \\
\text { No Board } \\
\text { seat }\end{array}$ & $\begin{array}{c}\text { Pressure: } \\
\text { Major } \\
\text { concession }\end{array}$ & $\begin{array}{c}\text { Pressure: } \\
\text { Minor } \\
\text { concession }\end{array}$ & $\begin{array}{c}\text { Proxy } \\
\text { Contest: } \\
\text { Board seat }\end{array}$ \\
\hline 23 & 7 & 24 & 13 & 17 \\
\hline \multicolumn{5}{|c|}{ Other Outcomes: 16\% } \\
\hline $\begin{array}{c}\text { Proxy } \\
\text { pentest }\end{array}$ & $\begin{array}{c}\text { Pressure } \\
\text { fails: } \\
\text { withdrawal }\end{array}$ & $\begin{array}{c}\text { Proxy } \\
\text { fails: } \\
\text { withdrawal }\end{array}$ & $\begin{array}{c}\text { Other } \\
\text { failure }\end{array}$ & $\begin{array}{c}\text { Outcome } \\
\text { open }\end{array}$ \\
\hline 2 & 2 & 1 & 2 & 9 \\
\hline
\end{tabular}

"Success" is defined capaciously to include any cognizable target concession. Cash payouts bring the target into the success category in $29 \%$ of the hostile cases. Other indicia of success include board membership (40\% of the hostile targets), sale or liquidation of the target $(28 \%)$, and the sale or the sale or spin off of a division $(21 \%) .{ }^{113}$ "Success" also includes minor concessions like investment banker engagement and governance overhauls.

The "success" classification entails a judgment call in one case, William Ackman's run at McDonald's in late 2005. McDonald's, rejecting his proposal, threw out a bone in the form of real estate sales abroad. Ackman withdrew, declaring victory, though at least one industry analyst suspected that McDonald's had been working on the foreign real estate sales long before Ackman's appearance. ${ }^{114}$ Ackman has been given the benefit of the doubt, with the case being categorized as one of "pressure: minor concession." But the failure characterization also fits. Indeed, Ackman's campaign transgressed two of activist Robert Chapman's "tenets of activism": first, avoid "weight-size mismatches"-here the target's size unduly raised the hurdle to forcing the issue with a proxy fight; and, second, avoid "credible incumbents" CEO's successful turnaround record lent credibility to the substantive rebuttal. Carl Icahn's attack on Time Warner presents another such case. Time Warner, a perennial burner of shareholder value, would appear to make an excellent target. Icahn invested in a serious substantive presentation, commissioning an elaborate restructuring plan from a blue chip investment banker. Wall Street nevertheless favored the company's CEO, Richard Parsons, and questioned Icahn's plan

113. Companies may overlap in the results for sale, asset sale, and cash payout.

114. See Dane Hamilton, Hedge Fund Drops Campaign Against McDonald's, ReUTERs News, Jan. 5 , 2006.

115. Christopher Faille, How (Not) To Be an Investor Activist: Object Lessons, HedGEWoRLD DaILY News, Mar. 6, 2006. 
on the merits. Icahn peremptorily dropped the campaign. The case nonetheless easily qualifies as a success under the standard here because Time Warner responded with a \$5-billion share buyback announcement, raising the amount to $\$ 20$ billion during the back-and-forth with Icahn. ${ }^{116}$

Table VI focuses on the large and mid capitalization firms in the subset of successful engagements. These targets emerge with a distinct profile within the group, reflecting the higher degree of difficulty and echoing Chapman's warning about weight to size mismatches. These targets show up in the successful subset in the same proportion as in the sample as a whole-they make up $39 \%$ of both. But, within the success subset, they tend to be underrepresented within the board seat category, most notably in the full dress proxy contests. Making up for this, they are overrepresented in the "pressure" category. Pressure without proxies makes cost/benefit sense for the activist: The bigger the target, the more expensive the proxy contest, but the greater the publicity generated by the activist campaign. The numbers showing that larger targets predominate in the cash payout and asset sale groups permit some inferences about the preferences of the larger targets' managers: Concrete economic concessions dominate over power sharing through board membership. The managers are not necessarily giving away the store in so doing-Part III will show that relatively modest amounts of cash are being paid out and many payouts are funded with the proceeds of asset sales.

\begin{tabular}{|c|c|c|c|c|c|c|c|c|}
\hline \multicolumn{2}{|c|}{ Table VI: Large and Mid Capitalization Targets (percent of the successful } \\
outcomes) \\
\hline Entire \\
$\begin{array}{c}\text { Settle- } \\
\text { ment: } \\
\text { successful } \\
\text { sample }\end{array}$ & $\begin{array}{c}\text { Settle- } \\
\text { Bent: } \\
\text { No } \\
\text { seat }\end{array}$ & $\begin{array}{c}\text { board } \\
\text { seat }\end{array}$ & $\begin{array}{c}\text { Pressure: } \\
\text { Major } \\
\text { concession }\end{array}$ & $\begin{array}{c}\text { Pressure: } \\
\text { Minor } \\
\text { concession }\end{array}$ & $\begin{array}{c}\text { Proxy } \\
\text { Contest: } \\
\text { Board seat }\end{array}$ & $\begin{array}{c}\text { Target } \\
\text { sold }\end{array}$ & $\begin{array}{c}\text { Cash } \\
\text { payout }\end{array}$ & $\begin{array}{c}\text { Asset } \\
\text { sold }\end{array}$ \\
\hline 39 & 28 & 48 & 58 & 57 & 17 & 33 & 58 & 45 \\
\hline
\end{tabular}

The pattern of activist demand and target response amounts to a strategic learning process, with both sides asking the same question: How much will it take to make the activists go away? That question has not yet been answered in many of these cases. Activist successes amount to closed cases only in $28 \%$ in which the target has agreed to be sold and in the $11 \%$ in which the activist has

116. See Bernard Condon, Buyback Boomlet, ForBes, May 22, 2006. General Motors is another case warranting special mention. It easily fits the success category due to concession of a board seat under pressure. But the activist, Kirk Kerkorian, and his board designee, Jerome York, lost their enthusiasm for the engagement when the CEO and the board proved unreceptive to their suggested business plan. York resigned; Kerkorian sold out. See Warren Brown. The Gambler Cashes Out, Ready for Another Game, WASH. Post, Dec. 10, 2006, at G2. 
taken control of the board of directors. In the majority of the cases where the fund has a minority stake on the board or continues to hold the stock after a partial concession, disagreement between target and activist remains a possibility. At the same time, an implicit commitment toward cooperative resolution of disputes obtains in the $40 \%$ of hostile cases in which the activist has gained board representation.

Most of the "other" outcomes set out in Table V are ongoing engagements yet to be determined. These undecideds are broken into two groups. In one group a proxy contest is proceeding or said to be in the works ( $2 \%$ of the sample) and in the other the hedge fund and the pressure remain (9\%), awaiting a concession.

Finally, we move to "failure"-defined as the hedge fund's failure to accomplish any of its governance objectives before terminating the engagement. This category, which includes only $5 \%$ of the sample, also includes a close case, Mellon Financial. There, Highfields Capital showed up in 2005 holding 2.12\% of the stock and demanding a split up. Mellon refused, and began purchasing assets. Highfields then sold 3.8 million of its 9 million shares, ${ }^{117}$ signaling retreat. But, with Relational Investors also holding a block of stock, Mellon faced a continuing threat. Mellon itself finally terminated the engagement in December 2006 when it agreed to merge with the Bank of New York in a merger of equals, a deal that accorded a (small) premium only to the Bank of New York shareholders. ${ }^{18}$ In another case in the failure category, Penn Virginia, the governance failure appears to stem from the investment's financial success. Boone Pickens started this campaign in 2002, putting an offer to purchase on the table and leaving it there for ten months to no effect. Pickens sold down to under $5 \%$ of the stock before the end of that year and has not been heard from since at Penn Virginia. ${ }^{119}$ Third Point Management, which already had taken a position in the stock, followed up in 2003, demanding a place on the board and threatening a proxy fight. The board refused the seat; Third Point did not initiate the fight, and subsequently sold down its holding the following year. ${ }^{120}$ If that were the entire story, the case would be anomalous, tenacity being a consistent activist attribute. But Third Point was close to having tripled its two-year investment when it sold, financial reality apparently trumping its governance agenda. Profit also accompanied the hedge fund's unwind in a third failure, Aspect Communications, one of the few lost proxy contests. ${ }^{121}$

The other three failures violate Robert Chapman's other two activist tenets:

117. Compare Highfields Capital Management LP (Form 13F-HR) (Nov. 14, 2005), with Highfields Capital Management LP (Form 13F-HR) (Feb. 14, 2006).

118. See Vipal Monga \& Peter Moreira, BoNY and Mellon Combine, TheDeal.com, Dec. 5, 2006.

119. For the last evidence of Pickens in the SEC file, see Penn Virginia Corp. (Schedule 13D/A) (Sept. 18, 2002) (filed by BP Capital Energy Equity Fund LP) (showing 6.5\% ownership).

120. Penn Virginia Corp. (Schedule 13D/A) (June 17, 2004) (filed by Third Point Management $\mathrm{Co}$. LLC) (selling below 5\%).

121. The hedge fund went in at $\$ 2.15$ to $\$ 3.44$. See Aspect Communications Corp. (Schedule 13D) (Dec. 30, 2002) (filed by Scepter Holdings Inc.). The time of exit is not clear, but the stock could not have been lower than $\$ 7.37$ during the period in question. 
no "poison prey"- the stock has to qualify as a good long-term hold on a passive basis; and no Pyrrhic victories-the stock must have potential to go up after a concession. ${ }^{122}$ In one case, Third Point went into a troubled firm, Salton Inc., at $\$ 6$ per share in September 2004. Third Point had ideas about its restructuring. ${ }^{123}$ It went out in April 2005 at $\$ 1.25$ to $\$ 1.60$, with nothing reported as having occurred during the interim. ${ }^{124}$ Two other troubled firms, Adelphia and Footstar complete the set. The former went into bankruptcy before the engagement had a chance to develop, and the latter looked to sale of the target as a stalling device. The hedge fund sold at a slight profit, before management decided to go into the Chapter. ${ }^{125}$

\section{SUMMARY}

The activists have an impressive record of success in the cases in the sample-so impressive that the record supports the proposition that they have shifted the balance of corporate power in the direction of outside shareholders and their financial agendas. But the proposition, once mooted, only triggers more questions. The leading question is whether this activist sector will continue to grow and become a permanent feature of the corporate landscape. If it does, it could occasion a modification of the prevailing description of a separation of ownership and control between shareholders and managers. Answering that question requires prognostication well beyond the scope of this Article, calling for projections respecting flows of investment capital into hedge funds and of the future relationship between corporate asset values and stock market capitalizations. If the flow of capital to the funds slows and market prices recover and match or exceed corporate asset values, hedge fund activists may fade in the manner of their cyclical predecessors, the legendary corporate raiders of the 1950s and 1980s. ${ }^{126}$

The sample can, however, assist in addressing other, lesser questions. The first is whether the hedge funds cause harm, draining productive enterprises of capital and molesting business plans and capital structures in search of shortterm profits. The second concerns the amount of those profits. Part III takes up these matters.

\section{Financial Outcomes}

This Part uncovers the light the sample sheds on four questions. The first, taken up in Section A, is whether the activists are short-term investors who extract cash and exit immediately. The answer is a clear no in all but a small

122. Faille, supra note 115.

123. Salton Inc. (Schedule 13D) (Sept. 20, 2004) (filed by Third Point Management Co. LLC).

124. Salton Inc. (Schedule 13D) (Apr. 27, 2005) (filed by Third Point LLC) (selling below 5\%).

125. See Footstar Inc. (Schedule 13D) (Jan. 15, 2004) (filed by Chap Cap Partners LP).

126. See Schurr, supra note 19, at 19 (discussing the cyclical nature of "activist onslaughts," which typically arrive after decades of relative market inactivity). 
number of cases. But the answer is less clear respecting the follow-up question of whether the activists are long-term investors. It is simply too soon in the history of hedge fund activist engagement for an answer to be forthcoming. The second question, taken up in Section B, is whether brutal cost cutting accompanies hedge fund intervention. The answer is no, subject to some exceptions. The third question, taken up in Section $\mathrm{C}$, is whether the activists are bringing back the high-leveraged restructuring of the $1980 \mathrm{~s}$, forcing firms to borrow to finance large cash payouts and leaving them with unsustainable capital structures. Here the answer again is a clear no in all but one case. The fourth question, taken up in Section $D$, is whether activism has yielded windfall profits that can be expected to lure ever-increasing numbers of reckless, inexperienced players. Here the answer is a more equivocal no.

\section{A. DURATION}

Hedge funds are said to invest short term, and short-term investment is said to be a bad thing. But why should that be? We like to tell ourselves in this country that ours are the world's best capital markets because they offer exceptional liquidity and liquidity means a lower cost of equity capital. ${ }^{127}$ This market advantage is precisely what makes short-term investment possible. Investors have taken full advantage. Average annual share turnover for firms listed on the New York Stock Exchange was 12\% in 1960. It rose to $73 \%$ in the heated market of $1987,{ }^{128}$ fell back thereafter, and then rose again to $82 \%$ in the heated market of $1999 .{ }^{129}$ For companies listed on the NASDAQ in 1999, annual turnover was three times higher-Amazon's stock turned over every seven days that year. ${ }^{130}$ But such churning, considered in isolation, presents a problem only for the investors who engage in it.

Short-term investors do become a problem when they influence management decisions. In the classic example, a manager who, left in isolation, would make a long-term investment that maximizes the value of the firm, foregoes the investment in order to boost accounting earnings in the near term and thereby maintain good relationships with the shareholders. Alternatively, the manager makes aggressive accounting decisions that improve earnings per share, only to stumble into destabilizing compliance problems. ${ }^{131}$ The appearance of institutional investors in the dominant shareholding role complicates this problem without solving it. Different institutional holders have different investment

127. See Erik Berglöf, Reforming Corporate Governance: Redirecting the European Agenda, EcoN. PoL'Y 93, 113 (1997).

128. See Kenneth Froot, Andre F. Perold \& Jeremy C. Stein, Shareholder Trading Practices and Corporate Investment Horizons, 5 J. APPLIED CORP. FIN. 42, 42 (1992).

129. John A. Byrne, When Capital Gets Antsy, Bus. WK., Sept. 13, 1999, at 72-76.

130. $I d$.

131. The heated markets of the late 1990s proved conducive to both situations. See Joseph Fuller \& Michael C. Jensen, Just Say No to Wall Street, 14 J. APpLIED CorP. Fin. 41, 42-43 (2002). 
styles, and many look primarily to near-term returns. ${ }^{132}$ Equity incentive pay schemes also complicate the problem without solving it because they omit constraints on disposition that would force their manager-beneficiaries to a long-term view. ${ }^{133}$ Long-term investors have not completely disappeared, however. The stock of blue chips like General Electric and Proctor \& Gamble took more than two years to turn over even in $1999 .{ }^{134}$ Managers seek out these long-term shareholders. ${ }^{135}$ Value investors usually are seen as a subset of the group.

The hedge funds present a potential problem despite their roots in the value investor segment. Their institutional structures put them in an intermediate time category, ${ }^{136}$ while performance pressures keep them focused on near-term gain. Accordingly, an activist could initiate a campaign with a view to getting a concession that appeals to the short-term shareholder interest and sell into the rising market that greets the concession. A cash payout or cost cutting restructuring that has this effect could meet the activist's objective even though it sacrifices long-term value.

The activists' time horizons accordingly bear on the question whether their interventions amount to a beneficial or detrimental application of capital market discipline. The sample provides a window through which to view their holding patterns. More particularly, the targets' and funds' SEC files have been reviewed to see whether the fund initiating each engagement retained at least $5 \%$ of the target's stock through December 31, 2006. Figure VII presents the results for the entire sample and a subsample comprised of engagements commenced before June 30,2005 . In the full sample, the fund is still there in $54 \%$ of the cases. ${ }^{137}$ In another $27 \%$, the target either has been sold or gone bankrupt, effectively terminating all-equity participations. The "split term" category (5\%) picks up cases where either (a) the fund sold a substantial part of its holding but still retains a substantial investment, or (b) a second fund joined the engagement and stayed on after the lead fund disinvested. "Sold" means what it says, and covers $12 \%$ of the targets. The label is assigned where the fund files a Schedule

132. See Brian J. Bushee, Do Institutional Investors Prefer Near-Term Earnings Over Long-Run Value 30 (Apr. 1999) (unpublished manuscript, on file with author), available at http://ssrn.com/ abstract $=161739$ (finding empirically that institutions overall have a weak preference for short-term earnings).

133. See William W. Bratton, Supersize Pay, Incentive Compatibility and the Volatile Shareholder Interest, 1 VA. L. \& BUS. REv. 55, 73-76 (2006) (discussing the negative effects that stock options, restricted stock, and other equity incentive payment schemes have on creation of long-term fundamental value).

134. Byrne, supra note 129 , at $72-73$ (noting that Proctor \& Gamble's average investment time was 25.1 months, while General Electric's was 33.1 months).

135. Toward that end, they have increased time spent on investor relations. $I d$. at $72-76$ (discussing the increased and differentiated efforts of managers to attract long-term investors).

136. See supra text accompanying note 45 .

137. Still there in that it owns $5 \%$ of the stock, or, in the few cases where the fund never amassed a $5 \%$ holding, evidence exists from the press or an SEC 13F filing supporting the inference that it remained on June 30, 2006. 


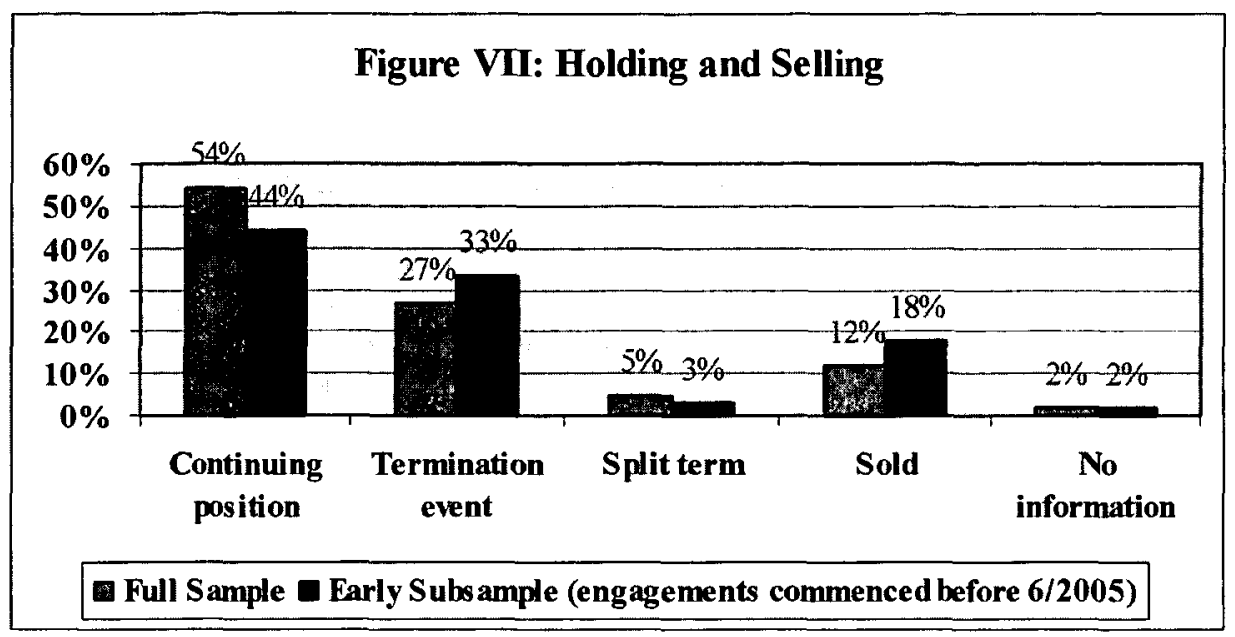

13D reporting that it owns less than 5\% of the stock and there is no subsequent evidence that it retains a substantial interest in the target. The sold targets are clumped in the sample's early years: eight of the fourteen sold engagements commenced between 2002 and 2004. Despite this, sold positions comprise only $18 \%$ of the early subsample.

Let us now apply this evidence to make the best case for the activists: In an impressive $81 \%$ of the cases in the full sample and $77 \%$ in the early subsample, they either have retained a substantial investment in the target or taken a payout on a pro rata basis with the target's other shareholders upon the sale of the company. Additional data bolsters the point. When an activist gains a seat on the board, it has a choice as to how to fill it. It may send one of its own principals, thereby constraining its trading ability due to an insider position, or it can send a designee and preserve some trading flexibility. ${ }^{138} \mathrm{~A}$ review of the sample to ascertain the identities of the activists' nominees reveals the following: Fund principals have joined the board (along with designees in some cases of more than one seat) in thirty-five cases, while a designee has been dispatched in eight cases. The practice, then, lies on the side of a time commitment.

We also need to take a look at the cases where the activist sold its shares. Four of these targets were held for two years or more, another five for one to two years, and eight for less than one year. We have already encountered three of them (Aspect, Penn Virginia, and Salton) above amongst the governance failures. Another two (Martha Stewart and Heidrick \& Struggles) were friendly investments. In two other cases (OfficeMax and PRG-Schultz), the fund extracted minor concessions and then sold into a falling market. Two cases (Unisource Energy and General Motors) saw an engagement of 11 months

138. See Barreto, supra note 53 ("[O]nce a manager joins the board[,] trading of the company's shares owned by the hedge fund would be restricted because of insider trading rules."). 
followed by an early exit at a slight profit. Things went better at five other cases in which the exit sales yielded substantial profits. In one of the five (MSC Software) the hedge fund first scored a settlement that provided board seats. It then reversed itself, unwound its settlement agreement and withdrew from the board to exit at the end of a year at a substantial profit. In another (Steve Madden), the target conceded only the appointment of an additional outside director, with the hedge fund holding for two years before taking its profit.

This leaves three cases. Here we finally do get a suggestion of opportunism. Carl Icahn was the activist in two of the three: Mylan Laboratories, described in the Introduction, and Temple-Inland. Icahn followed the same playbook with both-first, threaten and initiate a proxy contest, next get target to disgorge significant cash, and then quickly sell. The extraction of significant concessions in both cases removes any suggestion of misconduct - the payouts were shared pro rata with the other shareholders; neither case was a pump and dump in which Icahn sold the shares into a market buoyed solely by the news of his stake in the target. In fact, Icahn reversed course and reinvested in TempleInland soon after selling the stock. Only the last case, Gyrodyne, presents a classic abuse story; the abuse was greenmail. Pursuant to a settlement, $\mathrm{K}$ Capital sold its part of its holding back to issuer at a premium and the rest into the market. ${ }^{139}$ Significantly, K Capital was a short-termer in its other appearance in the sample, OfficeMax.

In sum, the activists' holding record, while not pristine, shows that most commit to their targets for at least the intermediate term. It is too soon to know how many of these commitments will endure into the long term. Meanwhile, the evidence, taken as a whole, does not sustain the claims of the activists' detractors.

\section{B. COST CUTTING}

Recall that activists often complain of excess costs, usually as to SG\&A, $R \& D$, or executive pay. In one famous case in the sample, BKF Capital Group, successful activists followed through with cuts only to face unexpected negative results. Steel Partners II (owning 8.7\%), in tandem with Carl Icahn \& Co. (owning 14.3\%), and Cannell Capital (owning 9.4\%), ${ }^{140}$ took three board seats at BKF after a proxy fight in 2005, with Steel's Warren Lichtenstein taking the board chairmanship. The group had fought and won on the ground that the firm paid excessive bonuses to its managers, including its founder and CEO, John A. Levin. When the new regime came in wielding its shareholder value cost clippers, Levin and most of the portfolio managers declined the haircut, resigning and taking the lion's share of the funds under management with them. The

139. See Gyrodyne Co. of America Inc. (Schedule 13D/A) (Apr. 17, 2002) (filed by K Capital Partners LLC).

140. See BKF Capital Group Inc., Definitive Proxy Statement (Schedule 14A), at 13 (May 26, 2006). 


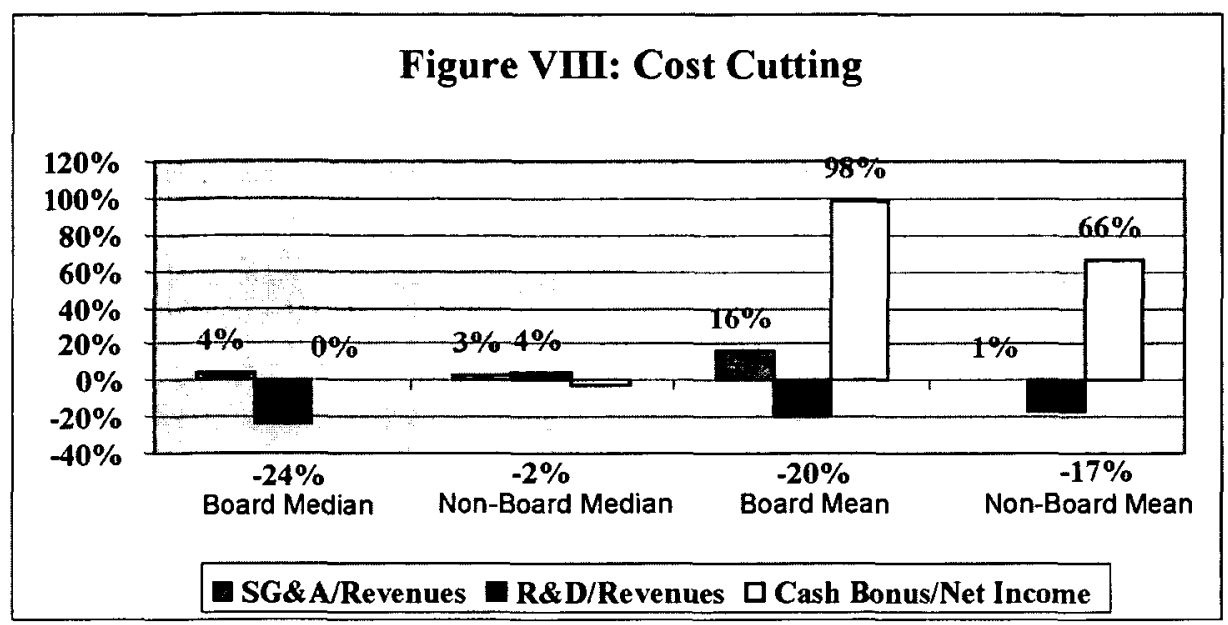

firm has not since recovered, and Lichtenstein has withdrawn as chair. ${ }^{141}$ The story has three morals: First, it warns us that successful activists can do harm. Here they took the out clippers at a firm built on personal relationships, ${ }^{142}$ apparently without pausing to ask about their management targets' job mobility. Second, the time commitment implied by an activist's presence on the board can be fragile. Third, when activists behave in ways calculated to advance their detractors' case, Carl Icahn never seems to be far away.

Meanwhile, a question arises respecting the activists' impact on cost levels at the other targets. To illustrate this, a subsample has been broken out, made up of firms in which the engagement began prior to 2006 and the activist retained its investment position on June 30, 2006. Ratios of SG\&A to revenues and R\&D to revenues were constructed from the firms' annual reports for three years before the engagement and all years since the engagement's commencement to the end of 2006. Ratios of cash bonuses paid to the firms' top executives (and reported in the annual proxy statement) to net income also were constructed, on the same before and after basis. A single before and after ratio was derived for each firm by averaging figures across multiple years. The firms were then divided into two classes, depending on whether a hedge fund representative had joined the board of directors.

Figure VIII reports the median and mean results. SG\&A is the cost that represents the largest cash outflow for the firms by far. The SG\&A to revenues ratio has risen in both subsets on both a mean and a median basis, indicating that no significant cost cutting occurred. It has gone differently with $R \& D$, an expense incurred in only thirteen of the fifty-two firms. Mean R\&D to revenues

141. See BKF Capital Group Inc. (Form 8-K) (Apr. 26, 2006).

142. See Joe Nocera, No Victors, Few Spoils in this Fight, N.Y. Times, July 22, 2006, at C1; see also Jenny Anderson, When Winning the Battle Leads to Losing the War, N.Y. TIMEs, Oct. 28, 2005, at C7. 
ratios dropped in both subsets, with a negative median result for the board representation firms and a slight increase for the others. But no inference of hedge fund causation can be drawn from the negative figures. In four of the firms with lower R\&D ratios, management already had been cutting aggressively in the years before the hedge fund's arrival. Moreover, R\&D expenditures actually went up in another seven of the thirteen firms; the negative ratios derive from the fact that the expenditures did not go up as much as revenues. The cash bonus medians are $0 \%$ and $-2 \%$, showing no tendency toward cuts. The bonus means signal substantial raises in executive pay. The group of firms that increased their bonus pool includes BKF Capital, which had to hire a new CEO.

The sample, then, does not suggest strong hedge fund impact on SG\&A, $\mathrm{R} \& \mathrm{D}$, and executive bonuses. Although there may have been some slashing and burning, its magnitude has been insufficient to skew the aggregate figures. This result is tentative, however. With time and boardroom influence, the activists may have more of an impact; in addition, a comparison with same-industry control firms might show an impact.

\section{CASH PAYOUTS AND BORROWING}

$\mathrm{BKF}$ is the only case in the sample where hedge fund intervention respecting a business plan has had manifestly adverse effects. But hedge funds also intervene on the financial side, pressuring firms to disgorge cash-either by substantially increasing a regular dividend, paying a special dividend, or repurchasing stock. Such payouts potentially weaken the targets by depriving their managers of ready capital to finance new projects. Whether this leads a target to forego a good project depends on the availability of alternate sources of finance, particularly debt capital. Such a constraint is most likely to result where a firm already is highly levered, or where, as with the high leverage restructurings of the 1980s, the firm borrows a substantial sum to finance the shareholder payout.

The financial statements of all targets were reviewed to isolate the firms making cash payouts to shareholders exceeding the level maintained prior to the commencement of activist engagement. A subset of forty-one firms emerged. ${ }^{143}$ Table VII displays aggregate amounts paid before December 31 , 2006 (or amounts to be paid in the case of firms that have announced specific payouts but have not yet effectuated them). The amounts correlate positively and proportionately with firm size-there is a $95 \%$ positive correlation between market capitalization and the firm's payment. But the payout subsample also contains a notable skew toward larger targets. The median market capitalization of the entire sample is $\$ 539$ million, while for

143. Payouts have been announced by an additional two targets: California Coastal and Mirant, the former stating an intent to finance through borrowing and the latter through cash on hand and an asset sale. 
payout firms it is $\$ 1.829$ billion. The percentage comparisons in Table VII expand on this point. Whereas large- and mid-capitalization firms make up $39 \%$ of the entire sample and only $21 \%$ of the cash-rich firms, they make up $56 \%$ of the payout firms.

\begin{tabular}{|l|c|c|c|c|c|}
\hline \multicolumn{7}{|c|}{ Table VII: Cash Payouts by Targets } \\
\hline & $\begin{array}{c}\text { Median } \\
\text { Amount Paid } \\
(\$ \text { million })\end{array}$ & $\begin{array}{c}\text { Mean } \\
\text { Amount Paid } \\
(\$ \text { million })\end{array}$ & $\begin{array}{c}\text { Percent of } \\
\text { Payout } \\
\text { Sample }\end{array}$ & $\begin{array}{c}\text { Percent of } \\
\text { Entire Sample }\end{array}$ & $\begin{array}{c}\text { Percent of } \\
\text { Cash-Rich } \\
\text { Targets }\end{array}$ \\
\hline Large Cap & 1,450 & 2,776 & 20 & 13 & 3 \\
\hline Mid Cap & 619 & 590 & 36 & 26 & 15 \\
\hline Small Cap & 26 & 65 & 44 & 61 & 82 \\
\hline
\end{tabular}

The disproportionate appearance of large firms makes sense-firms that make regular dividends and periodically repurchase shares come from largeand mid-capitalization sectors in the first place. ${ }^{144}$ Now add a fact-putting aside one friendly case in the payout group (Sears) $-82 \%$ of the large- and mid-capitalization firms making payments did so as a reaction to pressure; a relatively low $18 \%$ of these firms surrendered board seats. This confirms a point made earlier; larger firms that can afford it use their cash to buy off the activists and return to normalcy. This coin also has another side; when a large target has cash, the activist will manage to extract some of it. Of the large- and mid-sized firms that were cash-rich prior to the engagement, all show up in the payout group except three: Kmart, which used its cash to buy Sears; Siebel Systems, which was sold; and Earthlink, as to which an outcome remains pending.

Parallel observations can be made respecting the small capitalization firms in the payout subsample. Just as larger firms that are more able to pay dominate the subsample as a whole, firms with a notable ability to pay dominate the subsample's subset of small firms: $61 \%$ of the smaller firms in the payout group were cash rich ex ante.

We turn now to the payments and modes of funding. Sixteen of the firms in the subsample were cash rich ex ante-cash later depleted by activist induced payouts. Based on a review of the firms' cash flow statements, it appears that the ex ante cash afforded the exclusive source of paid out funds at ten firms, comprising $24 \%$ of the payout group. Carrying on the pattern distinguishing the larger and smaller firms, eight of the ten were in the small capitalization subset.

The remaining firms, whatever their size, looked to other means to finance

144. See Eugene F. Fama \& Kenneth R. French, Disappearing Dividends: Changing Firm Characteristics or Lower Propensity to Pay?, 60 J. FIN. Econ. 3, 19 (2001).

The subsample also contains seven firms (17\% of the subsample) that overlap with the small set of firms ( $12 \%$ of the whole sample) in which the activist sold out. This at least suggests that a hedge fund that extracts cash is more likely to disengage and go on to something else. 


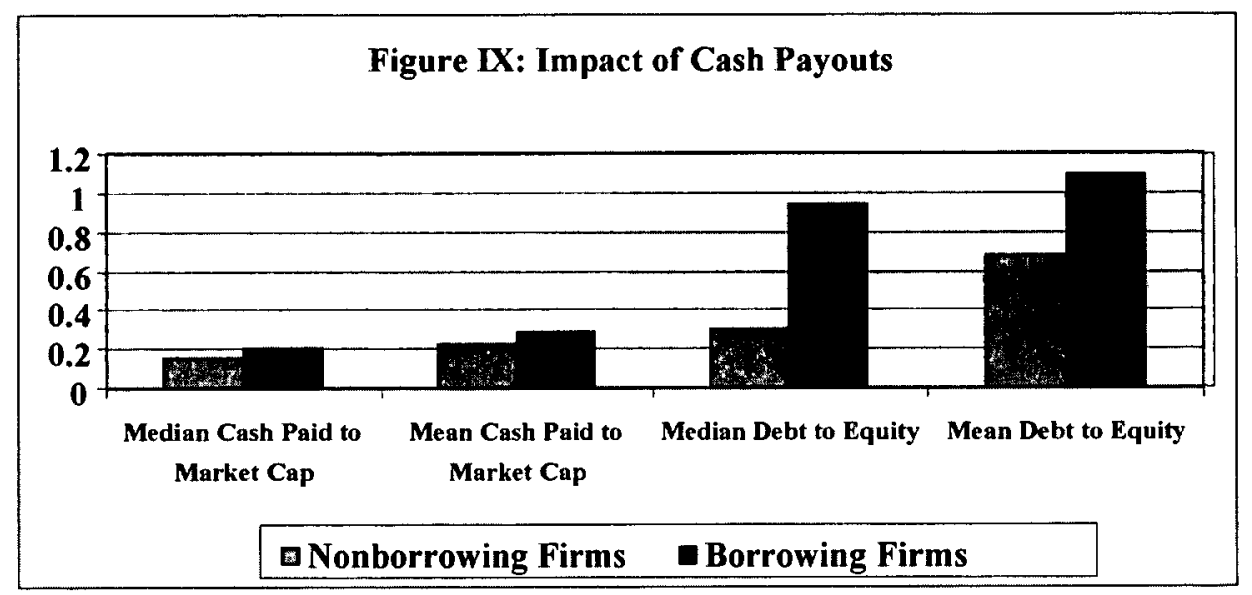

their payouts (or, in the case of six remaining cash-rich firms in the subsample, additional means). They had a choice of three-they either could borrow, sell an asset for cash, or rely on future periodic cash flows. Within the subsample, based on a review of the firms' cash flow statements, asset sale has been the leading choice-cash sales of assets preceded, and roughly matched, the payouts at eighteen firms (44\% of the subsample, overlapping with five of the cash-rich firms). There remains a group of thirteen firms who chose between cash flows from operations and borrowing. Of these, five have relied entirely on cash flows from operations. ${ }^{145}$ The remaining eight have borrowed. The loans are funding the payouts in part at two firms, Time Warner, which is mixing borrowing with cash flows from operations, and California Coastal, where loan proceeds combine with ex ante cash. Borrowing funds the entire payout at the remaining six-Mylan Labs, Stilwell Financial, Blockbuster, CBRL, Acxiom, and A. Shulman.

The eight borrowers emerge from their payouts with financial profiles distinct from the other firms in the subsample. Two sets of ratios have been constructed: cash paid out to ex ante market capitalization, and debt (short- and long-term) to shareholders' equity giving effect to the payout. (For announced but uncompleted payments, the ratios are constructed on a pro forma basis, utilizing the firm's most recent quarterly financials.) Figure IX compares the median and mean ratios for the nonborrowing and borrowing firms. The cash paid to market capitalization ratio measures the payouts' magnitude relative to firm size, letting us see whether resort to borrowing implies a bigger disgorgement. It does, by a

145. These are Time Warner, Temple Inland, New Century, PW Eagle, and Sylvan (which made a cash distribution prior to going private). A seventh firm, Mirant, has announced a $\$ 1.25$ billion repurchase tender offer to be funded mostly by cash, with part of the funding to come from the proceeds of a subsidiary borrowing already under way. Mirant has not been included with the borrowing cases because it plans to sell the subsidiary after the borrowing is completed. In substance, then, its source of funds will be a combination of cash and asset sale proceeds. 
small margin - the nonborrower median (mean) is $22 \%$ (16\%) compared to the borrowers' $29 \%$ (20\%). A starker differential emerges with the debt to equity comparison. The median (mean) borrower emerged with a debt to equity ratio of .94 (1.1), while the median (mean) nonborrower enjoyed a more comfortable $.29(.67)$.

It comes as no surprise that the activists responsible for three of the eight levered capital structures, Carl Icahn (Mylan and Blockbuster) and Nelson Peltz (CBRL) are 1980s veterans. Even so, the figures show that hedge fund activism has not been replaying the 1980s' leveraged restructuring. Deals in the 1980s took firms to debt equity ratios of 5 to 1 or 10 to $1 .^{146}$ Of the firms here, only one (CBRL) approaches that territory, with a ratio of 2.8 to 1 .

Both the small number of leverage cases (19.5\% of the payout firms) and the relative moderation of the supporting borrowing call for an explanation. Three complementary factors can be suggested. First, lending standards, while loosening, remain stricter than they were two decades ago. Second, the payouts are determined in a context of bargaining under constraint. Both sides weigh amounts against alternative courses of action. An activist that rejects a payout as too low may have to take the case for a higher payout to the shareholder group as a whole. There, the long-term shareholder interest will ask whether the financial course advocated could injure the firm. This constraint looms larger with larger targets, where the activist has less control over the vote. Third, the activist retains its stock ex post in most cases in the payout sample. The payout accordingly amounts to one phase of a broader campaign of value realization, and sale of the target at a premium remains salient as a possible end point. To the extent the class of potential buyers is expected to borrow to finance the purchase of the target, present levering impairs the sale. Such impairment is particularly likely to follow with private equity purchasers.

When the results and the explanations are considered together with the fact that corporate cash retention lately has come to be viewed as a problem, there results an evaluation decidedly in favor of activist intervention.

\section{PORTFOLIO RETURNS}

Hedge fund activism, by its own terms, is about shareholder value creation. A question accordingly arises about investment returns for the targets in the sample. Press reports on the activists' profits suggest the existence of a disciplinary bonanza of historic proportions. ${ }^{147}$ One might question whether the stock prices of the firms in the sample support these expansive inferences. To answer

146. See James C. Van Horne, Financial Management and Policy 727 (12th ed. 2001) (describing equity components of $10 \%$ in the late 1980 s).

147. See, e.g., Jenny Anderson, An Appetite for Fast Gains from Restaurant Chains, N.Y. Times, Feb. 10, 2006, at C7 (describing Pershing Square returns in 2005); Gregory Zuckerman, Big Shareholders Are Shouting Ever Louder-Activists Pressure Executives To Unlock Value, Even Using Pirate, Bulldog in Their Monikers, WALL ST. J., Nov. 23, 2005, at Cl (describing returns at Icahn and Steel Partners). 
this question, a portfolio comprised of 104 firms from the sample has been constructed. ${ }^{148}$ Portfolio positions commence as of the filing date of the activist's SEC Form 13D, with the purchase price pegged at the average of the high and low purchase prices reported in the filing. ${ }^{149}$ Termination dates and prices are as follows: (a) for continuing holds, the closing stock price on December 31, 2006, (b) the effective date of the merger for sold targets or December 31,2006 , for pending mergers, in either case at the merger price, ${ }^{150}$ (c) for sold positions, the date of the Form 13D announcing sale below $5 \%$ at the average of the high and low reported sale prices. ${ }^{151}$ Each of these investment positions is matched to a stock index position at the same start and termination dates. The targets are divided into large-, mid-, and small-capitalization firms and paired accordingly with the S\&P 500 Index, the S\&P 400 Mid-cap Index, or the S\&P 600 Small-cap Index. Returns are stated on the assumption that $\$ 100$ was invested on the commencement date. Three subsamples are broken out: continuing holds, merged targets, and sold positions.

It should be noted that this exercise is not directed to ascertaining investment returns at particular hedge funds. These cannot be determined with surety from public filings in any event-once a fund sells below $5 \%$, its trading results disappear from public view. Final returns to hedge fund investors are influenced by leverage and hedges, neither of which are made public. Also, this study is limited to domestic targets; the activists, in contrast, cross international borders. But we still can look at the prices of the firms in the sample to see whether hedge fund activists beat the market in the aggregate.

Table VIII sets out aggregate results. The activists, for the most part, have fared better than the market portfolio alternative. For the full sample, the hedge fund portfolio returned an average $39 \%$ while the market portfolio returned 27\%; for the continuing holds, the largest sub portfolio, the hedge fund portfolio returned an average $48 \%$ to $31 \%$ for the market index. The spread narrows considerably on the portfolios of merged and sold issues, to an average $25 \%$ over $22 \%$ for the merged companies and $26 \%$ to $16 \%$ for those sold.

148. Uncertainty as to holding period or financial result resulted in the omission of ten firms.

149. Where the filing reports no prices, the price is the consideration reported therein divided by the number of shares purchased; where no $13 \mathrm{D}$ has been filed, the price is the market price on the date of the first press report. In the case of Kmart/Sears, the price is the closing market price on the date Kmart emerged from bankruptcy.

150. In pending stock mergers, the consideration is calculated based on the purchaser's stock price on June 30, 2006.

151. No 13D was filed to announce exit from Adelphia; resolving doubts in favor of the activist, this date has been pegged one week following the filing of the 13D. Nor was a 13D filed announcing entry and exit from Temple-Inland. Here the Icahn firm's multiple entries and exits are ignored, and the dates are set at the target's first and last appearance on the firm's $13 \mathrm{~F}$ portfolio reports. 


\begin{tabular}{|l|c|c|c|c|}
\hline \multicolumn{5}{|c|}{ Table VIII: Portfolio Results } \\
\hline & $\begin{array}{c}\text { Full Sample } \\
(104)\end{array}$ & Held (62) & Merged (23) & Sold (19) \\
\hline $\begin{array}{c}\text { Hedge Fund Mean } \\
\text { (unweighted) }\end{array}$ & 139 & 148 & 125 & 126 \\
\hline Index Mean & 127 & 131 & 122 & 116 \\
\hline Hedge Fund Median & 118 & 117 & 132 & 116 \\
\hline Index Median & 119 & 123 & 120 & 116 \\
\hline $\begin{array}{c}\text { Hedge Fund Standard } \\
\text { Deviation }\end{array}$ & 124 & 148 & 44 & 106 \\
\hline $\begin{array}{c}\text { Index Standard } \\
\text { Deviation }\end{array}$ & 28 & 32 & 17 & 18 \\
\hline $\begin{array}{c}\text { Mean Holding Period } \\
\text { (months) }\end{array}$ & 21 & 25 & 18 & 12 \\
\hline $\begin{array}{c}\text { Hedge Fund Mean } \\
\text { (weighted by market } \\
\text { capitalization) }\end{array}$ & 164 & 183 & 108 & 123 \\
\hline
\end{tabular}

The hedge fund portfolio's return takes a jump to $64 \%$ when recalculated as an average weighted by each issue's market capitalization. This affords a fairer basis for comparing it with market portfolio returns, which reflect a weighted calculus. On a weighted basis, the best-performing portfolio in the sample is the portfolio of continuing hedge fund holds, which shows an $83 \%$ return on an average holding period of $25 \%$, against the market portfolio's $31 \%$. Contrariwise, the weighted hedge fund merger portfolio is the worst performer in the group at an $8 \%$ return over eighteen months. This fact implies that although the mergers yield premiums over market price, the merged firms have tended to experience antecedent stock market declines, with the declines cancelling out most of the merger gain and perhaps also weakening firm managers' bargaining position with the activist. It bears noting that as of the end of 2006 , no takers have been found for two targets in the held portfolio-Bally Fitness and Pep Boys-despite public auction processes. ${ }^{152} \mathrm{~A}$ different story explains the better return on the sold positions (23\% over an average twelve months with higher volatility). This portfolio is made up of big winners and big losers; either way, the fund sells out.

The sets of returns for the hedge fund portfolios have higher standard deviations than the market returns, signaling greater volatility of returns and a higher required rate of return. To see how much higher, the portfolio of

152. See Jesse Eisinger, 'Buy My Company, Please': Why Some Companies Go Unsold in Merger Boom, Wall St. J., Aug. 23, 2006, at C1 (citing James River Coal, to which the hedge fund later sold out at a loss). 


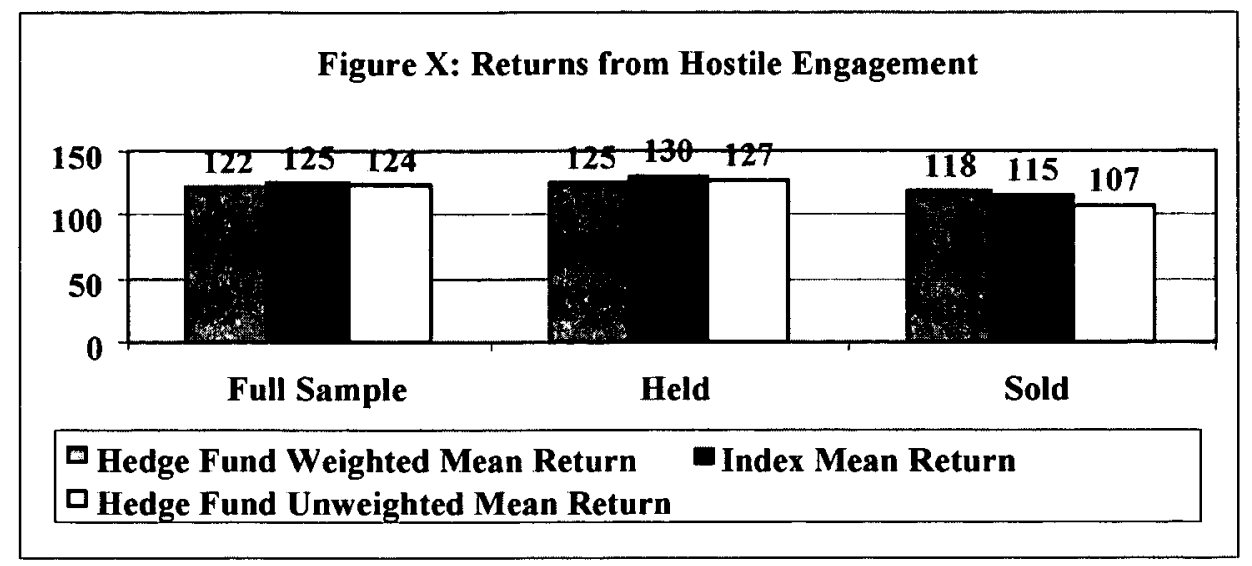

continuing holds has been analyzed within the Capital Asset Pricing Model. Five-year betas have been ascertained for seventy-two of the portfolio's seventyfour issues of stock. ${ }^{153}$ The mean beta is 1.24 and the weighted average beta is 1.37. Under the Model, using the long-term treasury return of $4.81 \%$ on December 31,2006 , and assuming a long-term market risk premium of $7 \%,{ }^{154}$ the hedge fund portfolio should be returning $1.7 \%$ (unweighted) or $2.6 \%$ (weighted) more than the market portfolio's expected return of $11.8 \%$. On this measure the held portfolio still easily beats the index portfolio.

One further adjustment needs to be made, however. Two of the biggest winners in the portfolio-Kmart/Sears and Martha Stewart—are friendly engagements. To get a clear picture of returns from hostile engagement, these and three other friendly investments should be taken out. Their removal substantially changes the results for the full, held, and sold portfolios; the merged portfolio has no friendly engagements. Figure $X$ depicts the adjustment's impact. It turns out that Sears did matter for the weighted portfolio. Its removal reverses the outcomes-now the market portfolio outperforms the unweighted hedge fund portfolio in all three samples and the weighted hedge fund portfolio for the full and held samples; the weighted hedge fund portfolio only squeaks out a $3 \%$ edge for the sold portfolio. By this measure, the hedge fund portfolio must be deemed suboptimal, at least as of December 31, 2006. ${ }^{155}$

153. Hoover's is the source. Two companies have no betas: Del Global Technologies (because it is on the pink sheets) and Mirant (because it is recently out of bankruptcy).

154. See Ivo Welch, Views of Financial Economists of the Equity Premium and on Professional Controversies, 73 J. Bus. 501, 502 (2000) (reporting on a survey of financial economists).

155. To see if dividends made a difference, dividends paid were added to stock price results for the held portfolio, calculated as of June 30, 2006. Returns increased as follows: unweighted from 142 to 145 , weighted from 155 to 158 , and weighted for the hostile subset from 110 to 112 . The results stand accordingly. Adding the dividends to the market comparisons would do at least this much.

A two-step weighting also was conducted, again as of June 30,2006 , taking into account the fact that the funds make smaller investments in large (median 6.7\%) and mid-sized (mean $7.8 \%$ ) than in 


\section{E. REGRESSION}

The data in the sample invite analysis in search of statistically significant causal relationships. Toward this end, the hedge fund portfolio results were restated as annualized internal rates of return so as to be suitable as a dependent variable in a multivariate regression analysis. Various governance results were regressed against the portfolio results as dummy variables: settlement without board membership, settlement with board membership, pressure-major concession, pressure-minor concession, board membership through proxy fight, proxy failure, pending, open, and board control. Prior performance against the industry was also regressed against the portfolio results. Only one variable proved even weakly significant-settlement without board membership. But this did not prove robust compared to alternative specifications such as taking the logarithm of the internal rate of return.

\section{F. SUMMARY}

We have seen that indefinite term investments predominate in the sample and that large cash payouts, while a salient result of intervention, have not crippled the targets. Nor, except in one case, have we seen any destructive cost cutting; indeed, we have not seen much cost cutting at all. What we have seen is that it is not safe to assume that one would beat the market by investing in a portfolio of hedge fund targets.

In the picture that emerges, activist investment is a high risk/high return enterprise. Nothing guarantees above-market returns when a hedge fund manager assembles a significant block of stock in a likely-looking company and then gets on the phone with its managers and demands immediate value. The long-term winners will be those who play the game most skillfully, both as stock pickers and as management interlocutors. Some observers might at this point project a risk that players desperate for success at any cost will pile on unreasonable demands, thereby damaging their targets. While this could happen, nothing requires target managers to increase their concessions in response. Cupidity drives the plays in a game like this one, whether or not the players beat the market on average. The question is whether the cupidity is bridled or unbridled, and the constraints described in this Part suggest a bridle (or at least a halter).

\section{Hedge Fund Activism and the Market for Corporate Control}

Mergers and acquisitions figure prominently as occasions for activist intervention. As with Icahn and Mylan, intervention can occur against a firm in the

small-sized (9.6\%) targets. The market capitalizations of each firm in the sample were weighted to reflect this difference (large: $27.8 \%$; mid: $32.4 \%$; small: $39.8 \%$ ) before the calculation of weighted portfolio returns. The results for the portfolios improve very slightly after omitting friendly investments: 110.4 for the full portfolio, 110.6 for the held portfolio, 103.9 for the merged portfolio, and 115.5 for the sold portfolio. 
process of acquiring another firm, with the objective of terminating the transaction. Intervention can also occur against a firm being acquired, with the objective of securing a higher price. Intervention often comes without a deal on the table, with the objective of forcing the target to put itself up for sale. Finally, in Mylan and a number of other cases in the sample, the intervening activist makes an offer to buy the target. These four points of intersection between hedge fund activism and the market for corporate control raise two distinct policy questions: First, whether activist disruption of management planning is more or less likely to have perverse effects with mergers than in other cases. Second, whether activism heralds a return of the hostile tender offer, reviving associated policy questions with respect to target tender offer defenses.

Section A sets out the results from merger cases yielded in this Article's survey. Section B traverses the problem of perverse effects, suggesting it to be minimal. Section C considers the activists' offers to purchase, concluding that no revival of the hostile takeover is in the offing.

\section{A. THE SAMPLE}

The database search brought up twenty-five cases, listed in Appendix B, in which a merger announcement triggered activist intervention. Nine of the targets in this group are also included in the sample chiefly because the activist stayed on for an extended engagement after the merger transaction's disposition. The other sixteen cases involve no overlap because there is no evidence of further hedge fund engagement with the target. ${ }^{156}$

A taxonomic distinction follows. The sixteen additional cases involve shareholder intervention respecting a single transaction. Such sideline input from Wall Street has been a fact of life in the acquisitions market for three decades, generated by merger arbitrageurs seeking to make sure the target gets sold at the maximum possible amount. Most of the additional cases in the sample follow this long-standing motivational pattern. The cast of activist characters changes accordingly, with firms like Perry Corporation and Elliott Associates showing up in addition to the activist firms that pursue longer engagements. The time horizon changes also, with tighter focus on near-term gain.

A survey of the twenty-five listed transactions reconfirms the point that the activists influence results. Only five transactions in the group closed with their terms unaltered. Seven of the remaining twenty closed only after concessions, usually a price increase, with thirteen terminated entirely. Note that the former result will be pursued by a fund with a long position in the merger target, while the latter result will be pursued by a fund with a long position in the buyer. Funds with such opposing interests have come into open conflict in only two of the cases, however. In the rest, the funds show up on one side only, either as stockholders of the buyer seeking to terminate the deal (eight cases), or as

156. In one of these (Pharmacopeia/EOS Biotechnology), the objecting intervener was a long-term investor in the acquiring firm. There is no subsequent evidence of intervention, however. 
stockholders of the selling firm seeking to get the deal's terms improved (fifteen cases).

Out of ten deals attacked on the buy side, only one deal closed untouched. Eight were terminated, and a ninth closed with the activist being conceded a board seat. Six of these ten challenges fall in the subset overlapping the sample in chief. Buy side intervention, then, tends to implicate a diagnosis of governance problems and a longer engagement, even though it can also implicate a short term stock price gain achieved through deal termination. Sell side intervention is more likely to focus only on the transaction, as the intervener looks for a short term gain through a price increase.

The sell side challenges have a broader range of results. Four of the transactions closed unaltered; four closed after price concessions; and three were terminated in the wake of a higher offer from a third party. Five were terminated without a higher bid on the table, implicating the loss of a premium, albeit a premium deemed too low. Significantly, four of these terminations occurred in the overlap category, with activist pressure leading to a later sale in two of the four cases. In a third case, the activist sits on the board of the unsold company. In the remaining two termination cases, an inside blockholder was attempting to take the firm private at an overly attractive price, leaving open an ongoing conflict with the public shareholders.

\section{B. POLICY IMPLICATIONS}

The corporate law of mergers and acquisitions devotes itself to assuring that the selling shareholders get a fair price, deploying fiduciary duties and appraisal rights to that end. While investors may object to the price in a particular deal, in a world where premiums range between $20 \%$ and $50 \%,{ }^{157}$ no one deems selling prices as amounting to a policy problem. The problem lies on the opposite side-a fair selling price can mean an excessive purchase price. Corporate law, however, is more relaxed about fairness to buy side shareholders. In the usual case, the board of directors' decision to purchase lies in business judgment territory and appraisal rights are not obtained. ${ }^{158}$ At best, the dissatisfied purchasing shareholders have a vote, ${ }^{159}$ and hence a collective action problem in imposing their view that the deal is bad.

Many purchases turn out to be just that. The merger premium appears in most cases to be so substantial as to arrogate the entire merger gain to the selling

157. See supra text accompanying note 63.

158. Del. CODE ANN. tit. 8, § 262(b)(1) (2001) (denying appraisal rights for shareholders of listed companies and shareholders not entitled to vote on the merger).

159. But not in all cases. See DEL. CODE ANN. tit. 8, §§ 251(c),(f) (2001) (providing for a shareholder vote unless, inter alia, the number of new buyer shares issued in the merger exceeds $20 \%$ ). A buyer can get around the vote by organizing a subsidiary corporation to conduct the transaction. Stock exchange rules constrain this move, however. See N.Y. Stock Exchange Listed Company Manual $\$ 312.03$ (2004) (requiring a vote in any case where the number of buyer shares increases in an amount equal to or greater than $20 \%$ ). 
shareholders. Studies of announcement period price effects bear out this assertion with a stark allocational picture. While the selling firm's shares go up a consistent $16 \%$ during the three days surrounding an announcement, the purchaser's shares go down - the average was $-0.3 \%$ in the $1970 \mathrm{~s},-0.4 \%$ in the $1980 \mathrm{~s}$, and $-1.0 \%$ in the $1990 \mathrm{~s} .{ }^{160}$ Over a time window of several months, target shares average an increase of $23.8 \%$, while buyer shares on average go down around $4 \% .^{161}$ The figures imply consistent losses to buy side shareholders.

A reference to portfolio theory makes the results less disturbing. Most purchasing firm shareholders own their shares in diversified portfolios. Thus, they stand on both sides of the deal and so are indifferent to the division of gain as between the parties to the deal. ${ }^{162}$ So long as the combined result for the two firms nets out positive, everything is fine. And such was the overall case until the late 1990s: from 1973 to 1998 , the combined three day window result averaged a positive $1.8 \%$; from 1980 to 1989 , the average was $2.6 \%$; and from 1990 to 1998 the figure was $1.4 \% .^{163}$

Unfortunately, a cluster of mergers in the late 1990s reversed the $1.8 \%$ long-term positive. Moeller, Schingemann, and Stulz marshal some shocking three-day announcement returns. They show that from 1980 to 1990 , purchasing firms' shares lost an aggregate $\$ 4$ billion, and from 1990 to 1997 they gained $\$ 24$ billion. From 1998 to 2001 , however, they lost $\$ 240$ billion, bringing down the 1990 to 2001 result to a $\$ 216$ billion buyer loss. The 1998 to 2001 numbers are so bad that they make for a negative combined result of $\$ 134$ billion for buyers and sellers in the period. ${ }^{164}$ The negative dominoes fall from there. Where in the 1980s combined returns were a positive $\$ 12$ billion, from 1991 to 2001 the combined loss was $\$ 90$ billion. ${ }^{165}$ That nets out to a $\$ 78$ billion loss for 1980 to 2001 . $^{166}$

160. Gregor Andrade, Mark Mitchell \& Erik Stafford, New Evidence and Perspectives on Mergers, 15 J. ECON. Perps. 103, 109-10 (2001).

161. Id. The decline was $-4.5 \%$ in the $1970 \mathrm{~s},-3.1 \%$ in the $1980 \mathrm{~s}$, and $-3.9 \%$ in the $1990 \mathrm{~s}$. Id. There is literature that sorts for the characteristics of bidder firms with low abnormal returns. The results are summarized as follows: abnormal returns are lower for (1) low leverage firms, (2) low Tobin's q firms, (3) firms with large cash holdings, (4) firms with low managerial ownership of shares, and (5) large capitalization firms. Sara B. Moeller, Frederick P. Schlingemann \& Rene M. Stulz, Wealth Destruction on a Massive Scale? A Study of Acquiring-Firm Returns in the Recent Merger Wave, 60 J. FIN. 757, 770 (2005). Lower abnormal returns are also associated with certain transactions: (1) public firm targets, (2) target opposition, (3) conglomerate results, (4) competitive bidding, and (5) stock consideration. Id. at 770-71.

162. Robert G. Hansen \& John R. Lott, Jr., Externalities and Corporate Objectives in a World with Diversified Shareholders/Consumers, 31 J. Fin. \& Quantitative ANALYsis 43, 47 (1996) (noting that an investor holding a diversified portfolio with stock in both corporations is concerned with the total gain from the transaction, not with how the gain is allocated).

163. Andrade, Mitchell \& Stafford, supra note 160 , at 110.

164. Moeller, Schlingemann \& Stulz, supra note 161 , at 758-59.

165. Id. at 763 .

166. These disastrous results stem from eighty-seven deals out of a total of 4,136 in the authors' sample. Id. at 765 . The most prominent common feature among the purchasing firms involved was prior acquisition behavior. The purchasing firms are serial acquirers with high market valuations. In the past 
Herein lies a great potential for the activists to do some good, just by enhancing the chance of shareholder disruption of a friendly merger. The managers of a potential buyer now have to worry about attack on two fronts. Complaints by dissatisfied selling shareholders (and the fiduciary duties of the seller's managers) continue to increase the likelihood of renegotiation for a higher price or the appearance of a third party with a higher offer. ${ }^{167}$ But now the buyers' own shareholders may be in a position to register their objections effectively, with the objection implying a credible threat to the firms' business plan and the incumbency of its managers. Prudent managers accordingly will take more care in selecting, structuring, and pricing their transactions.

The question arises whether intimidated managers will be deterred from entering into beneficial combinations. This seems highly unlikely for three reasons: First, because deal pressure arises within industries, managers proactively look for acquisitions as means of self-defense. Second, the markets are full of intermediaries who add to deal pressure in order to generate fees. Third, the markets are also full of institutional investors looking for sell-side premiums, the hedge funds prime among them. Note that the balance of pressure in the sample lies squarely on the selling side. Even when an activist intervenes to terminate a purchase, it often does so for the purpose of turning the buyer into a seller. One suspects that buy/sell standoffs, as in Mylan, will not occur very often. But, when they do, we should not presume them to be harmful.

\section{ACTIVISTS AS PURCHASERS}

Commentators on hedge fund activism project an evolution toward hostile tender offers. ${ }^{168}$ This projection makes sense. The distinction between hedge funds and private equity becomes less and less clear as hedge funds enter into the bidding for companies going private. At the same time, the hedge funds do not share private equity's reputational interest in cooperative engagement. Put the two points together, and hedge fund activism finally ripens into a replay of the hostile takeover boom of the 1980s.

Although the projection makes structural sense, it finds little support in the sample. The activists have indeed made offers to purchase. Recall that Carl Icahn put an offer on the table in Mylan, only to withdraw it upon achieving the objective of a large cash payout. Offers were also made in seventeen other cases in the sample in chief. ${ }^{169}$ This time Icahn's case is typical. None of the eighteen offers has led to a merger. Although the offers are "hostile," only three resulted

they had made value enhancing acquisitions. Moeller, Schlingemann, and Stulz suggest that the pattern of success caused an increase in the managers' zone of discretion. The managers then push the acquisition pattern too far and the market withdraws its support. Id. at 760, 777.

167. See Shearer, supra note 15.

168. See Shearer, supra note 68; Fishman-Lapin, supra note 15.

169. They are MaxWorldWide, TCSI, Gyrodyne, Footstar, GenCorp, Wells Financial, General Motors, MSC Software, Blair Corp., Circuit City, Beverly Enterprises Inc., Blockbuster Video, Cenveo Inc., PRG-Schultz Int., Acxiom, Whitehall Jewellers, and Houston Exploration. 
in a filing of a formal SEC Form TO (General Motors, Acxiom and Whitehall). Two of the three, Kirk Kerkorian's tender for General Motors stock and Value Act's tender for Acxiom, should be put to one side. Kerkorian's GM offer, although not only initiated but closed, served only to increase the offeror's 3\% ownership stake to $7.2 \%$, not to secure control of the firm. ${ }^{170}$ Value Act's offer, now withdrawn after a settlement, was similar-it would have increased its stake from $11.7 \%$ to $19.9 \%$ of the stock and was conditioned on its slate being elected in an upcoming election. ${ }^{171}$ Whitehall was different. There the hedge fund eventually submitted a bid at an auction conducted by the target. The same thing happened in one other case (Beverly). But both times the hedge fund just happened to have been beaten by a slightly higher offer $(\$ 0.10$ and $\$ 0.30$, respectively). Nor have their offers on the whole been generous, with a median premium of $20 \%$. In one case (Circuit City) the press commented that the offer was a transparent ploy to put the company in play ${ }^{172}$ so that someone else would take it over. The same point seems appropriate in the other cases. The ploy has succeeded in four (MaxWorldWide, TCSI, Beverly, and Whitehall). Significantly, it did not succeed in the other thirteen cases. An offer remains on the table in one of these (Houston Exploration). In the rest, the offer to purchase faded out as the engagement took its course.

\section{SUMMARY}

The activists come to the merger market on both sides of the transactions. On the sell side, they augment standing pressure for higher premiums. On the buy side they interject a welcome note of resistance, forcing acquiring firms to take more care against overpaying. As yet, there is no sign of a revival of the hostile tender offer.

\section{CONCLUSION}

This Article's survey of activist intervention rebuts two allegations made by the hedge funds' critics. The interventions neither amount to near-term holdups nor revive the 1980s leveraged restructuring. Today's pattern is more moderate than that of twenty years ago. Engagements in the 1980s tended to have all or nothing outcomes-either the activist took over the firm, the firm went private or otherwise paid off its shareholders with the proceeds of a leveraged restructuring, or the firm stayed independent, perhaps after making a greenmail payment. Today's activism triggers changes in control in only a minority of the cases; when control does change it tends to mean a sale to a third party rather than to the activist. Today's cash payouts, while substantial, do not imply radical transformations of the targets' capital structures. Today's activists often use their

170. See General Motors Corp. (Schedule TO/A), at 2 (July 20, 2005) (filed by Tracinda Corp.).

171. See Acxiom Corp. (Schedule TO-C) (June 21, 2006) (filed by VA Partners LLC).

172. Andrew Ross Sorkin, They're All Paying Customers to Wall Street, N.Y. Tomes, Dec. 11, 2005, $\S 3$, at 5 . 
power to acquire board seats, as occurred in $40 \%$ of the sample's hostile cases.

This is the survey's most interesting result: With boardroom entry come fiduciary duties to the entity as a whole and an implicit commitment to pursue the value agenda in a cooperative framework, much as Warren Buffett has always done. At the same time, the activists' independence and financial stakes imply a more critical stance toward management initiatives than heretofore forthcoming from outside directors. The activists thereby present a new variation on the blockholder theme, more distanced from management and arguably better positioned to approach corporate governance's theoretical ideal of a vigorous outside monitor. Whether the activists succeed in mediating between their agendas as fund managers and as boardroom fiduciaries remains to be seen. Meanwhile, they conduct an important experiment in corporate governance.

Two other results coexist in tension. On the one hand, the activists' record of governance success is impressive enough to support the proposition that they have shifted the balance of corporate power in the direction of outside shareholders and their financial agendas, perhaps heralding a modification of the prevailing description of a separation of ownership and control. On the other hand, the stock portfolio comparisons, taken together with the changing financial and performance characteristics of the targets, cast doubt onto the existence of financial incentives sufficient to support a significant alteration of the governance equilibrium. The tension can best be resolved with a warning that too much should not be made of either result. We will see more cases like McDonald's as managers move up the learning curve. At the same time, the portfolio results are just a market snapshot as of the close at the end of 2006. Note that continuing positions make up the largest and best performing of the three portfolios. In every one of those cases, the activist, by hypothesis, has determined that the stock price does not yet reflect the firm's intrinsic value; had it thought otherwise, it would have sold and disengaged from a governance role at the target. For financial results speaking to incentives, we must wait for the long-term. That only makes sense-as the survey shows, hedge fund activism does not tend to be a short term enterprise.

The portfolio results may have meaning for the short term, however. They signal that corporate governance has not left twenty dollar bills lying on Wall Street to be picked up by any portfolio manager who looks down. The new shareholder activism, although distinguished by its combination of a value perspective and impatience, turns out to call for patience and skill. The prediction is not that incentives are lacking, but that some practitioners will do much better than others. 
APPENDIX A: GOVERNANCE INTERVENTION SAMPLE

\begin{tabular}{|c|c|c|c|}
\hline Company & Year & Hedge Fund & $\begin{array}{c}\text { Maximum percent } \\
\text { owned (*reporting } \\
\text { group) }\end{array}$ \\
\hline Pizza Inn Inc. & 2002 & Newcastle Partners & 40.8 \\
\hline Reader's Digest & 2002 & Highfields Capital Mgmt. & 9.19 \\
\hline MeVC Fund & 2002 & Millennium Partners & 7.18 \\
\hline Vista Bancorp & 2002 & Seidman Associates & 12.5 \\
\hline Martha Stewart Living & 2002 & ValueAct Capital & 22 \\
\hline Penn Virginia & 2002 & $\begin{array}{l}\text { BP Capital Energy } \\
\text { (Boone Pickens) }\end{array}$ & 14.7 \\
\hline Brantley Capital & 2002 & Philip Goldstein & 6.7 \\
\hline Autodesk & 2002 & ValueAct Capital & 4 \\
\hline MaxWorldWide & 2002 & Newcastle Partners & 11.5 \\
\hline Liquid Audio & 2002 & Steel Partners II & 17.6 \\
\hline SL Indus. & 2002 & Steel Partners II & 28.6 \\
\hline Sylvan Inc & 2002 & Steel Partners II & 9.6 \\
\hline Del Global Technologies & 2002 & Steel Partners II & 7.6 \\
\hline TCSI & 2002 & Newcastle Partners & 12.8 \\
\hline Stilwell Fin. Inc. (Janus) & 2002 & Highfields Capital Mgmt. & 8.9 \\
\hline Alliance Bancorp of NE & 2002 & Lawrence Seidman & 6.2 \\
\hline Adelphia Communications & 2002 & Highfields Capital Mgmt. & 9 \\
\hline Heidrick \& Struggles Int'l & 2002 & Eminence Capital & 11.29 \\
\hline Gyrodyne Co. of America & 2002 & K Capital & 18.72 \\
\hline Aspect Communications & 2003 & Scepter Holdings & 6.6 \\
\hline Kmart & 2003 & ESL Partners & 52.6 \\
\hline Potlatch Corp. & 2003 & Franklin Mutual Advisors & 15.5 \\
\hline Nautica & 2003 & ESL Partners & 9.55 \\
\hline Sears & 2003 & Barington Partners & 9.5 \\
\hline Intercept Inc. & 2004 & JANA Partners & 7.1 \\
\hline Footstar Inc. & 2004 & Chapman Capital & 7.1 \\
\hline Farmer Bros. & 2004 & Franklin Mutual Advisors & 13 \\
\hline Angelica Corp. & 2004 & Cannell Capital & 19.6 \\
\hline Warwick Valley Tel. & 2004 & Santa Monica Partners & 2.1 \\
\hline Bally Total Fitness & 2004 & Liberation Inv. Group & 11.2 \\
\hline Steven Madden Ltd. & 2004 & Barington Capital Group & 7.59 \\
\hline The Stephan Co. & 2004 & Merlin Partners & 7.5 \\
\hline
\end{tabular}




\begin{tabular}{|c|c|c|c|}
\hline Company & Year & Hedge Fund & $\begin{array}{c}\text { Maximum percent } \\
\text { owned (*reporting } \\
\text { group) }\end{array}$ \\
\hline SPX Corp. & 2004 & $\begin{array}{l}\text { Atlantic Investment } \\
\text { Mgmt. }\end{array}$ & 7 \\
\hline Argonaut Technologies & 2004 & Jewelcor Mgmt. & 6.4 \\
\hline Novoste (now Novt) & 2004 & Steel Partners II & 14.9 \\
\hline Cornell Cos. & 2004 & Pirate Capital & 16.6 \\
\hline GenCorp Inc. & 2004 & Steel Partners II & 9.8 \\
\hline NDCHealth & 2004 & MMI Investments & 9.7 \\
\hline Mylan Laboratories & 2004 & Carl Icahn \& Co. & 6.8 \\
\hline Wells Fin. Corp. & 2004 & Opportunity Partners & 8 \\
\hline BKF Capital Group Inc. & 2004 & Steel Partners II & 8.7 \\
\hline RedEnvelope Inc. & 2004 & Scott Galloway & $19.8^{*}$ \\
\hline MSC Software & 2005 & Value Act Capital & 11.06 \\
\hline Salton Inc. & 2005 & Third Point Mgmt. & 6 \\
\hline Blair Corp. & 2005 & Santa Monica Partners & $6.8^{*}$ \\
\hline Temple-Inland & 2005 & Carl Icahn \& Co. & 2 \\
\hline Circuit City & 2005 & Highfields Capital Mgmt. & 7.8 \\
\hline Kerr-McGee Corp. & 2005 & Carl Icahn \& Co. & 7.6 \\
\hline Beverly Enterprises Inc. & 2005 & Appaloosa Mgmt. & $8^{*}$ \\
\hline OfficeMax & 2005 & K Capital Partners & 8.6 \\
\hline Krispy Kreme Doughnuts & 2005 & Courage Capital & 12 \\
\hline Star Gas Partners & 2005 & Third Point Mgmt. & 6.2 \\
\hline Unisource Energy & 2005 & Third Point Mgmt. & 8.5 \\
\hline Siebel Systems & 2005 & $\begin{array}{l}\text { Providence Recovery } \\
\text { Partners }\end{array}$ & 5.5 \\
\hline Blockbuster Video & 2005 & Carl Icahn & 8.84 \\
\hline Wendy's Int'l & 2005 & Highfields Capital Mgmt. & 9.3 \\
\hline Weyerhaeuser & 2005 & Franklin Mutual Advisors & 7.1 \\
\hline Topps Co. & 2005 & Pembridge Capital Mgmt. & 1 \\
\hline Walter Indus. & 2005 & Appaloosa Mgmt. & 15.3 \\
\hline Artesyn Technologies & 2005 & Jana Partners & 10.3 \\
\hline A. Schulman & 2005 & Barington Capital Group & 10.77 \\
\hline Register.com Inc & 2005 & Barington Capital Group & $20^{*}$ \\
\hline Brinks Co. & 2005 & Pirate Capital & 8.3 \\
\hline Cenveo Inc. & 2005 & Burton Capital Mgmt. & 11 \\
\hline Time Warner & 2005 & Carl Icahn \& Co. & 3 \\
\hline
\end{tabular}




\begin{tabular}{|c|c|c|c|}
\hline Company & Year & Hedge Fund & $\begin{array}{l}\text { Maximum percent } \\
\text { owned (*reporting } \\
\text { group) }\end{array}$ \\
\hline PRG-Schultz Int & 2005 & Cannell Capital & $9.5^{*}$ \\
\hline Western Gas Resources & 2005 & Third Point Mgmt. & 8.6 \\
\hline Acxiom Corp. & 2005 & Value Act Capital & 12 \\
\hline Computer Horizons Corp. & 2005 & Crescendo Partners & 11 \\
\hline Cutter \& Buck & 2005 & Pirate Capital & 14.6 \\
\hline Massey Energy & 2005 & Jana Partners & 6.5 \\
\hline New Century Fin. & 2005 & Greenlight Capital & 9.1 \\
\hline EarthLink Inc. & 2005 & Steel Partners II & 5.3 \\
\hline Ligand Pharmaceuticals & 2005 & Third Point Mgmt. & 9.5 \\
\hline Visteon Corp. & 2005 & Pardus Capital Mgmt. & 15.6 \\
\hline Phelps Dodge & 2005 & Atticus Capital & 9.99 \\
\hline McDonald's & 2005 & Pershing Square & 4.9 \\
\hline Novell & 2005 & Tudor Inv. Corp. & 5 \\
\hline EnPro Indus. & 2005 & Steel Partners II & 14.8 \\
\hline Sovereign Bancorp & 2005 & Relational Investors & 6.69 \\
\hline NWH & 2005 & Chapman Capital & 7.1 \\
\hline Exar Corp. & 2005 & GWA Investments & 1.76 \\
\hline Six Flags Inc. & 2005 & Red Zone (Dan Snyder) & 9.8 \\
\hline Reynolds and Reynolds Co. & 2005 & ValueAct Capital & 12.5 \\
\hline Knight-Ridder & 2005 & $\begin{array}{l}\text { Private Capital Mgmt. } \\
\text { (Legg Mason) }\end{array}$ & 19 \\
\hline Pep Boys & 2005 & $\begin{array}{l}\text { Barington Cos. Equity } \\
\text { Partners }\end{array}$ & 13.87 \\
\hline Sitel Corp. & 2005 & Jana Partners & 14.5 \\
\hline General Motors & 2005 & $\begin{array}{l}\text { Tracinda Corp. (Kirk } \\
\text { Kerkorian) }\end{array}$ & 9.9 \\
\hline Spartan Stores & 2005 & Loeb Partners & 6.44 \\
\hline Whitehall Jewelers & 2006 & Newcastle Partners & 12 \\
\hline Mellon Fin. & 2006 & Highfields Capital Mgmt. & 2.12 \\
\hline Wegener Crop & 2006 & Henry Partners & 7.3 \\
\hline Synergy Fin. Group & 2006 & Financial Edge Fund & 9.99 \\
\hline Astoria Fin. Corp. & 2006 & PL Capital & 0.44 \\
\hline CKE Restaurants & 2006 & Pirate Capital & 11.8 \\
\hline $\begin{array}{l}\text { CBRL Group-Cracker } \\
\text { Barrel }\end{array}$ & 2006 & Trian Partners & 4.8 \\
\hline NorthWestern Corp. & 2006 & Harbinger Capital Partners & 20 \\
\hline
\end{tabular}




\begin{tabular}{|l|c|l|c|}
\hline \multicolumn{1}{|c|}{ Company } & Year & \multicolumn{1}{|c|}{ Hedge Fund } & $\begin{array}{c}\text { Maximum percent } \\
\text { owned (*reporting } \\
\text { group) }\end{array}$ \\
\hline Tyco Int'l & 2006 & Omega Advisors & 0.3 \\
\hline H.J. Heinz & 2006 & Trian Partners & 5.6 \\
\hline James River Coal Co. & 2006 & Pirate Capital & 14.5 \\
\hline InfoUSA & 2006 & Dolphin Limited P'ship & 3.7 \\
\hline TechTeam Global Inc. & 2006 & Costa Brava P'ship III & 11.7 \\
\hline LifePoint Hospitals Inc. & 2006 & Accipiter Capital Mgmt. & 1.8 \\
\hline Reliant Energy & 2006 & Seneca Capital Advisors & 1.4 \\
\hline New York Times & 2006 & $\begin{array}{l}\text { Morgan Stanley } \\
\text { Investment Mgmt. }\end{array}$ & 7.5 \\
\hline Houston Exploration & 2006 & Jana Partners & 14.8 \\
\hline NABI Pharmaceuticals & 2006 & Third Point Mgmt. & 9.5 \\
\hline California Coastal & 2006 & Mellon HBV Alternative & 11 \\
\hline Communities & 2006 & Liberation Inv. Group & 8.4 \\
\hline Multimedia Games & 2006 & Pirate Capital & 5.3 \\
\hline OSI Restaurant Partners & 2006 & Chapman Capital & 5.6 \\
\hline Carreker Corp. & 2006 & Caxton Corp. & $27.6 *$ \\
\hline PW Eagle & 2006 & Pirate Capital & 1.6 \\
\hline Mirant Corp. & 2006 & CD Capital Mgmt. & 9.7 \\
\hline Sunterra Corp. & & \\
\hline
\end{tabular}


APPENDIX B:

Merger Intervention Sample

\begin{tabular}{|c|c|c|c|}
\hline Cases Overlapping Sample & Year & Intervention & Outcome \\
\hline Liquid Audio & 2002 & Buy Side & $\begin{array}{l}\text { Terminated (shareholder } \\
\text { vote) }\end{array}$ \\
\hline Mylan Laboratories & 2004 & Both Sides & $\begin{array}{l}\text { Terminated (adverse } \\
\text { facts discovered) }\end{array}$ \\
\hline The Stephan Co. & 2004 & Sell Side & $\begin{array}{l}\text { Terminated (shareholder } \\
\text { vote) }\end{array}$ \\
\hline Computer Horizons Corp. & 2005 & Buy Side & $\begin{array}{l}\text { Terminated (shareholder } \\
\text { vote) }\end{array}$ \\
\hline Spartan Stores & 2005 & Buy Side & Terminated (pressure) \\
\hline Sovereign Bancorp & 2005 & Buy Side & Closed with concessions \\
\hline Artesyn Technologies & 2005 & Sell Side & Terminated (pressure) \\
\hline InfoUSA & 2006 & Sell Side & Terminated (pressure) \\
\hline Mirant/NRG Energy & 2006 & Buy Side & Terminated (pressure) \\
\hline \multicolumn{4}{|l|}{ Additional Cases } \\
\hline $\begin{array}{l}\text { Pharmacopeia/EOS } \\
\text { Biotechnology }\end{array}$ & 2002 & Buy Side & Terminated (pressure) \\
\hline MONY/AXA & 2003 & Sell Side & Closed with concessions \\
\hline Texas Genco/NRG Energy & 2004 & Sell Side & Closed \\
\hline Hollywood Entertainment Inc. & 2004 & Sell Side & Terminated (pressure) \\
\hline IMS Health Inc./VNU & 2005 & Buy side & Terminated (pressure) \\
\hline Transkaryotic/Shire PLC & 2005 & Sell Side & Closed \\
\hline MCI/Verizon & 2005 & Sell Side & Closed with concessions \\
\hline Molson/Coors & 2005 & Sell Side & Closed with concessions \\
\hline Inamed/Medicis & 2005 & Sell Side & $\begin{array}{l}\text { Terminated (higher } \\
\text { offer) }\end{array}$ \\
\hline $\begin{array}{l}\text { Providian Fin./ Washington } \\
\text { Mutual }\end{array}$ & 2005 & Sell Side & Closed \\
\hline ShopKo Stores/Goldner Hawn & 2005 & Sell Side & $\begin{array}{l}\text { Terminated (higher } \\
\text { offer) }\end{array}$ \\
\hline Symantec/Veritas & 2005 & Buy side & Closed \\
\hline Intellisync/Nokia & 2005 & Sell Side & Closed \\
\hline Chiron Corp. & 2006 & Sell Side & $\begin{array}{l}\text { Closing with } \\
\text { concessions pending }\end{array}$ \\
\hline Guidant/Boston Scientific & 2006 & Sell Side & $\begin{array}{l}\text { Closed (competitive } \\
\text { bids) }\end{array}$ \\
\hline Lexar Media/Micron & 2006 & Sell Side & Closed with concessions \\
\hline
\end{tabular}


